\title{
Electrochemically induced transformations of bi- and trinuclear heterometallic vinylidene complexes containing $\mathrm{Re}, \mathrm{Pd}$ and Fe
}

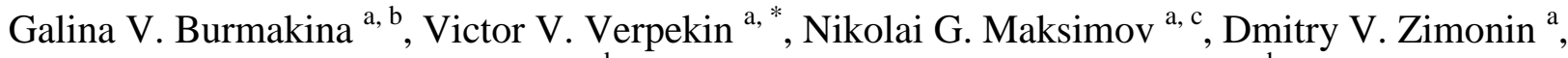 \\ Dmitry A. Piryazev ${ }^{\mathrm{d}}$, Oleg S. Chudin ${ }^{\mathrm{a}}$, Anatoly I. Rubaylo ${ }^{\mathrm{a}, \mathrm{b}, \mathrm{c}}$ \\ ${ }^{a}$ Institute of Chemistry and Chemical Technology SB RAS, Federal Research Center \\ “Krasnoyarsk Science Center SB RAS”, Akademgorodok, 50-24, Krasnoyarsk 660036, Russia \\ ${ }^{6}$ Siberian Federal University, Svobodny Prospect., 79, Krasnoyarsk 660041, Russia \\ ${ }^{c}$ Federal Research Center "Krasnoyarsk Science Center SB RAS", \\ Akademgorodok, 50, Krasnoyarsk 660036, Russia \\ ${ }^{d}$ Nikolaev Institute of Inorganic Chemistry, Siberian Branch of the Russian Academy of \\ Sciences, Acad. Lavrentiev Ave., 3, Novosibirsk, 630090, Russia
}

\begin{abstract}
Redox-induced transformations of bi- $\quad\left(\mathrm{Cp}(\mathrm{CO})_{2} \operatorname{RePd}(\mu-\mathrm{C}=\mathrm{CHPh})\left(\mathrm{PPh}_{3}\right)_{2}\right.$ $\mathrm{Cp}(\mathrm{CO})_{2} \operatorname{RePd}(\mu-\mathrm{C}=\mathrm{CHPh})(\mathrm{P}-\mathrm{P}) \quad\left[\mathrm{P}-\mathrm{P}=\eta^{2}-\mathrm{Ph}_{2} \mathrm{P}\left(\mathrm{CH}_{2}\right)_{2} \mathrm{PPh}_{2} \quad(\mathrm{dppe}) \quad(\mathbf{3}), \eta^{2}-\mathrm{Ph}_{2} \mathrm{P}\left(\mathrm{CH}_{2}\right)_{3} \mathrm{PPh}_{2}\right.$ (dppp) (4)], $\quad \mathrm{Cp}(\mathrm{CO})_{2} \mathbf{R e F e}(\mu-\mathrm{C}=\mathrm{CHPh})(\mathrm{CO})_{4} \quad(\mathbf{5}) \quad$ and trinuclear $\quad\left(\mathrm{Cp}(\mathrm{CO})_{2} \mathbf{R e F e}_{2}\left(\mu_{3^{-}}\right.\right.$ $\mathrm{C}=\mathrm{CHPh})(\mathrm{CO})_{6} \quad(\mathbf{6}), \quad \mathrm{Cp} \operatorname{ReFePd}\left(\mu_{3}-\mathrm{C}=\mathrm{CHPh}\right)(\mathrm{CO})_{5}(\mathrm{P}-\mathrm{P}) \quad[\mathrm{P}-\mathrm{P}=\mathrm{dppe} \quad(\mathbf{7}), \quad \mathrm{dppp} \quad(\mathbf{8})]$ heterometallic vinylidene complexes derived from $\mathrm{Cp}(\mathrm{CO})_{2} \mathbf{R e}=\mathrm{C}=\mathrm{CHPh}(\mathbf{1})$ were investigated by electrochemical methods. The oxidation processes of clusters $\mathbf{7}$ and $\mathbf{8}$ were studied by EPR spectroscopy. The electrochemical properties of clusters $\mathbf{7}$ and $\mathbf{8}$ were shown to depend on the nature of the chelate diphosphine ligand at the palladium center in contrast to complexes $\mathbf{3}$ and $\mathbf{4}$. The oxidation of complexes 2-4 was found to result in the Re-Pd, Pd- $C^{1}$ bond cleavage and formation of rhenium complex $\mathbf{1}$ and $\mathbf{P d}$-containing fragments. The oxidation of $\mathbf{7}$ and $\mathbf{8}$ resulted in the formation of the radical cations $\mathbf{7}^{+\bullet}$ and $\mathbf{8}^{+\bullet}$, which gradually transformed into a number of intermediate products: $\quad \mathrm{Cp}(\mathrm{CO})_{2} \operatorname{RePd}(\mu-\mathrm{C}=\mathrm{CHPh})(\mathrm{P}-\mathrm{P}), \quad\left[\mathbf{F e}(\mathrm{CO})_{3}\right]^{+\bullet}, \quad\left[\mathrm{Cp} \mathbf{R e F e}_{2}\left(\mu_{3^{-}}\right.\right.$ $\left.\mathrm{C}=\mathrm{CHPh})(\mathrm{CO})_{6}\right]^{+\bullet}$ and others. The final products of their oxidation in both cases were triangular clusters $(\mathrm{CO})_{\mathbf{8}} \mathrm{Fe}_{2} \mathbf{P d}(\mathrm{P}-\mathrm{P})[\mathrm{P}-\mathrm{P}=\operatorname{dppe}(\mathbf{9})$, dppp (10)] and rhenium complex 1. The molecular structure of cluster 7 was established by X-ray diffraction analysis.
\end{abstract}

\section{Introduction}

Heterometallic complexes and clusters have attracted considerable attention since they exhibit catalytic properties [1-17] and, therefore, may serve as model systems for understanding the rearrangements of organic molecules on polymetallic surfaces [18-20]. Indeed, polynuclear metal species exhibit the ability to change the chemical properties of the coordinated ligands and, thus, to activate new rearrangements as a consequence of the cooperativity effects of the metal 
centers working in concert [21-25]. In this context, the interactions between metal cores and coordinated ligands in such compounds have extensively been studied.

Some of the reactions of transition metal complexes and clusters are known to proceed through redox mechanisms. So, the investigation of such reactions requires the application of electrochemical methods that offer the direct determination of the redox characteristics of the compounds and extensively used in organometallic chemistry. However, a combination of electrochemical and spectroscopic research methods makes it possible to study the pathways of the redox reactions of complexes and clusters and determines the products of their electrochemical transformations [26, 27]. It is well-known that the electrochemical reactions of polymetallic compounds can be either reversible or irreversible (in which case the metal cores undergo transformations) [28-32]. Moreover, their electrochemical properties and oxidation mechanisms depend on their composition and structure.

Heteronuclear complexes and clusters containing bridging vinylidene ligands are one type of such compounds, a wide variety of which was constructed by the reactions of mononuclear vinylidene complexes of manganese, rhenium $\mathrm{Cp}(\mathrm{CO})_{2} \mathrm{M}=\mathrm{C}=\mathrm{CHR}(\mathrm{M}=\mathrm{Mn}$ [3336]; $\mathrm{M}=\operatorname{Re}$ [37-40]) and rhodium $\mathrm{Cp}\left(\mathrm{PPr}^{\mathrm{i}}\right) \mathrm{Rh}=\mathrm{C}=\mathrm{CH}_{2}$ [41-43] with unsaturated metalcontaining fragments. These heterometallic compounds have quite similar structures of their central fragments $\mathrm{MM}^{\prime}\left(\mu-\mathrm{C}=\mathrm{CRR}^{\prime}\right)$ or $\mathrm{MM}^{\prime} \mathrm{M}^{\prime \prime}\left(\mu_{3}-\mathrm{C}=\mathrm{CRR}\right)$ and at the same time they can contain different transition metals and a ligands, which provide an opportunity to regulate the redox properties of the compounds.

The electrochemistry of mononuclear manganese, rhenium, and rhodium vinylidene complexes and related compounds was summarized in the reviews of Bianchini [44-46], Pombeiro [47], Ustynyuk [48] and their co-workers. The redox properties and processes of oxidative dehydromerization of rhenium and manganese vinylidene complexes $\mathrm{Cp}(\mathrm{CO})_{2} \mathrm{M}=\mathrm{C}=\mathrm{CHPh}$, and catalytic electrochemical proton reduction based on the manganese phenylvinylidene complex were studied by Ustynyuk's group in detail [49-51].

The results of the electrochemical study of binuclear $\mu$-vinylidene complexes $\mathrm{Cp}(\mathrm{CO})_{2} \mathrm{MnM}(\mu-\mathrm{C}=\mathrm{CHPh}) \mathrm{LL}^{\prime}\left(\mathrm{M}=\mathrm{Pt}, \mathrm{Pd}, \mathrm{L}, \mathrm{L}^{\prime}=\mathrm{CO}, \mathrm{P}(\mathrm{OPr}-\mathrm{i})_{3}, \mathrm{PPh}_{3}, \mathrm{P}(\mathrm{OPh})_{3}, \mathrm{~L}^{-\mathrm{L}^{\prime}}=\right.$ $\mathrm{Ph}_{2} \mathrm{P}\left(\mathrm{CH}_{2}\right)_{\mathrm{n}} \mathrm{PPh}_{2}, \mathrm{n}=1$ (dppm), 2 (dppe), 3 (dppp)) [52-57], $\mathrm{Cp}(\mathrm{CO})_{2} \operatorname{RePt}\left(\mu-\mathrm{C}^{1}=\mathrm{C}^{2} \mathrm{HPh}\right) \mathrm{L}_{2} \quad\left(\mathrm{~L}_{2}\right.$ $=2 \mathrm{PPh}_{3}$, dppm, dppe, dppp) [58], dimeric compounds $\left[\mathrm{Cp}(\mathrm{CO})_{2} \mathrm{M}(\mu-\mathrm{C}=\mathrm{CHPh}) \mathrm{CuCl}\right]_{2}(\mathrm{M}=$ $\mathrm{Mn}, \mathrm{Re})$ [59-61] and trinuclear clusters $\mathrm{CpMnFePt}\left(\mu_{3}-\mathrm{C}=\mathrm{CHPh}\right)(\mathrm{CO})_{5} \mathrm{LL}^{\prime}\left(\mathrm{L}, \mathrm{L}^{\prime}=\mathrm{CO}, \mathrm{PPh}_{3}\right.$, $\left.\mathrm{P}(\mathrm{OPr}-\mathrm{i})_{3}, \mathrm{~L}-\mathrm{L}^{\prime}=\mathrm{dppm}\right)$ [53-56] were reported in our previous papers. The redox properties of vinylidene clusters $\left(\mu_{3}-\mathrm{C}=\mathrm{CHPh}\right) \mathrm{FeCo}_{2}(\mathrm{CO})_{7} \mathrm{dppm},\left(\mu_{3}-\mathrm{C}=\mathrm{CHPh}\right) \mathrm{FeCo}_{2}(\mathrm{CO})_{9-\mathrm{n}} \mathrm{L}_{\mathrm{n}}\left[\mathrm{L}=\mathrm{PPh}_{3}(\mathrm{n}\right.$ 

$=1$,
2),
$\mathrm{AsPh}_{3}$
( $\mathrm{n} \quad=$
$1)]$,
and
$\left[\mathrm{Os}_{3}(\mathrm{CO})_{8}\left\{\mu_{3}, \eta^{2}-\right.\right.$

$\left.\left.\left\{\mathrm{C}=\mathrm{CHC}(\mathrm{O}) \mathrm{CH}=\mathrm{CH}\left(\mathrm{C}_{5} \mathrm{H}_{4}\right) \mathrm{Fe}\left(\mathrm{C}_{5} \mathrm{H}_{5}\right)\right\}\left(\mathrm{SCH}_{2} \mathrm{CH}_{2} \mathrm{~S}\right)\right\}\right]$ were studied in [62, 63].

In our previous work [64] we reported the consecutive metalation of the mononuclear vinylidene complex $\mathrm{Cp}(\mathrm{CO})_{2} \mathbf{R e}=\mathrm{C}=\mathrm{CHPh}(\mathbf{1})$, resulting in a series of binuclear complexes 2-4 and trinuclear clusters 7, 8 (Scheme 1).

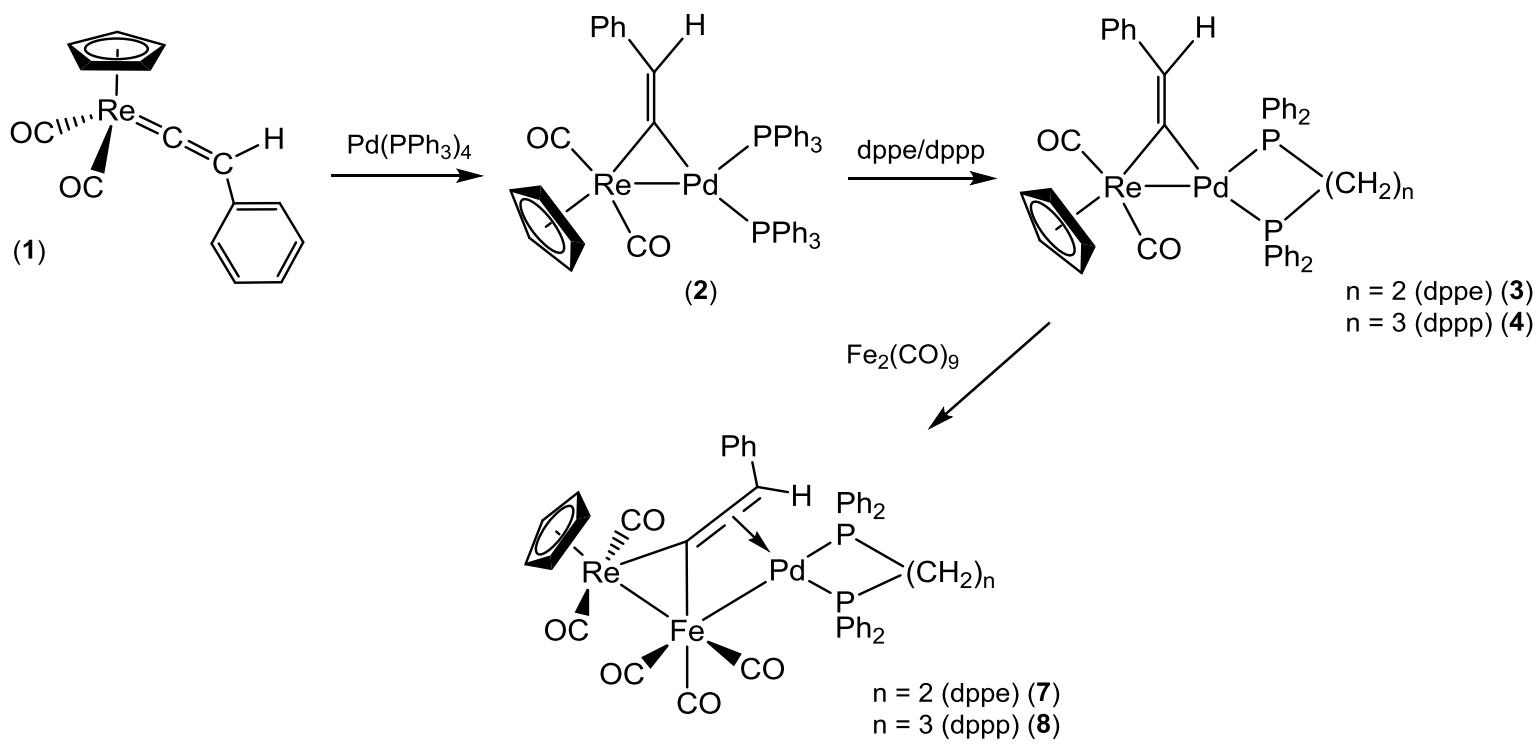

Scheme 1 .

We also demonstrated that these ReFePd clusters can further react with $\mathrm{Fe}_{2}(\mathrm{CO})_{9}$ to give the mixtures of $\mathrm{Cp}(\mathrm{CO})_{2} \operatorname{ReFe}(\mu-\mathrm{C}=\mathrm{CHPh})(\mathrm{CO})_{4}(\mathbf{5}), \mathrm{CpReFe}_{2}\left(\mu_{3}-\mathrm{C}=\mathrm{CHPh}\right)(\mathrm{CO})_{8}(\mathbf{6})$ and $(\mathrm{P}-$ $\mathrm{P}) \mathrm{PdFe}_{2}(\mathrm{CO})_{8}(\mathrm{P}-\mathrm{P}=\operatorname{dppe}(\mathbf{9}), \operatorname{dppp}(\mathbf{1 0}))($ Scheme 2$)$.
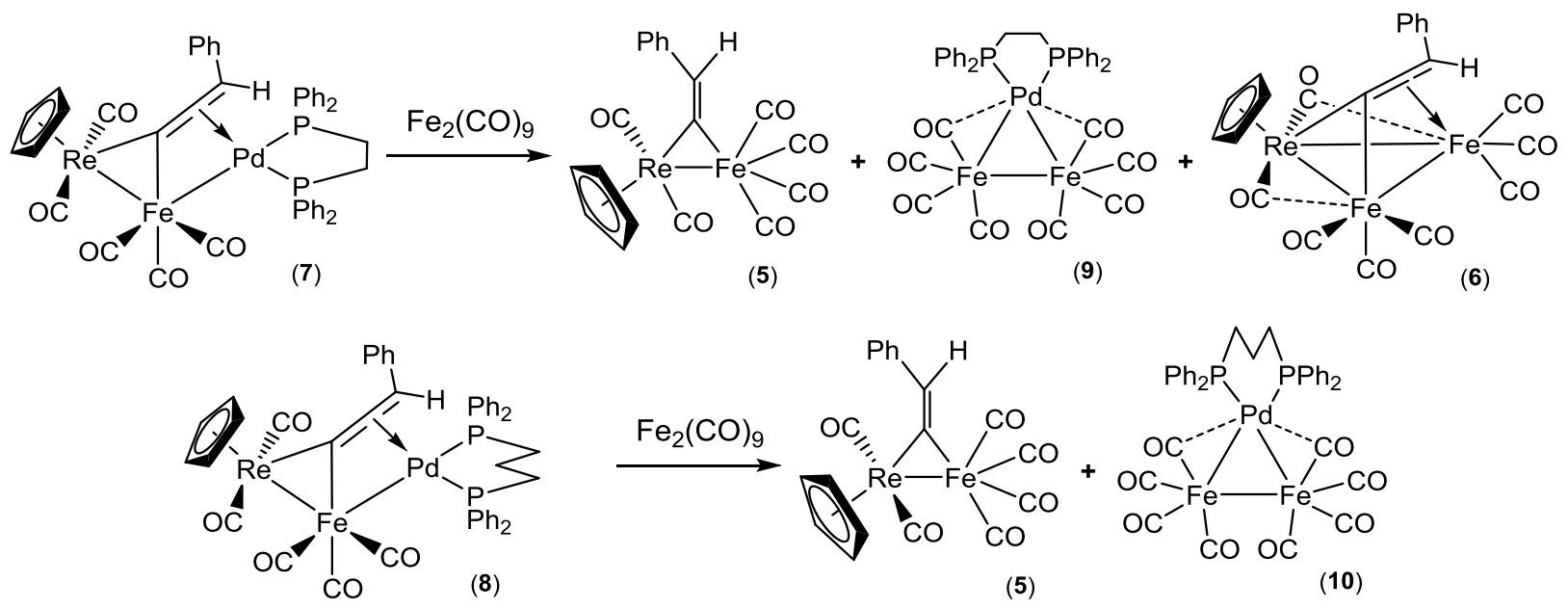

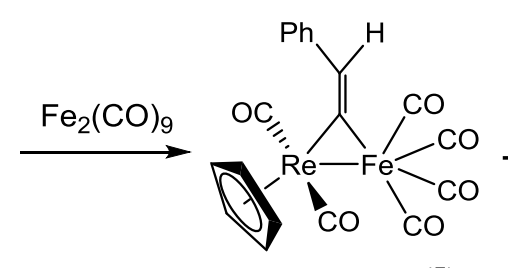

(5)

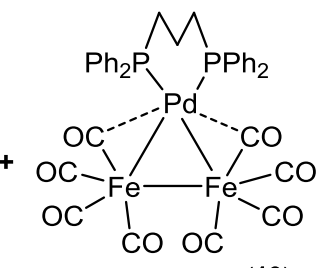

(10)

Scheme 2.

Here, we report the electrochemical study of redox transformations of heterometallic vinylidene binuclear complexes $\mathrm{Cp}(\mathrm{CO})_{2} \operatorname{RePd}(\mu-\mathrm{C}=\mathrm{CHPh})\left(\mathrm{PPh}_{3}\right)_{2}$

(2), $\mathrm{Cp}(\mathrm{CO})_{2} \operatorname{RePd}(\mu-$ 
$\mathrm{C}=\mathrm{CHPh})(\mathrm{P}-\mathrm{P}) \quad\left[\mathrm{P}-\mathrm{P}=\eta^{2}-\mathrm{Ph}_{2} \mathrm{P}\left(\mathrm{CH}_{2}\right)_{2} \mathrm{PPh}_{2}\right.$ (dppe) (3), $\eta^{2}-\mathrm{Ph}_{2} \mathrm{P}\left(\mathrm{CH}_{2}\right)_{3} \mathrm{PPh}_{2}$ (dppp) (4)] and trinuclear clusters $\mathrm{Cp} \operatorname{ReFePd}\left(\mu_{3}-\mathrm{C}=\mathrm{CHPh}\right)(\mathrm{CO})_{5}(\mathrm{P}-\mathrm{P})$ [P-P = dppe (7), dppp (8)]. Additionally, the electrochemical properties of complex $\mathrm{Cp}(\mathrm{CO})_{2} \operatorname{ReFe}(\mu-\mathrm{C}=\mathrm{CHPh})(\mathrm{CO})_{4}(\mathbf{5})$, and cluster $\mathrm{Cp}(\mathrm{CO})_{2} \mathbf{R e F e}_{2}\left(\mu_{3}-\mathrm{C}=\mathrm{CHPh}\right)(\mathrm{CO})_{6}(\mathbf{6})$ are studied to establish the exact pathways of redoxreactions of compounds $\mathbf{7}$ and $\mathbf{8}$. The redox characteristics of the previously synthesized compounds $(\mathrm{CO})_{8} \mathbf{F e}_{2} \mathbf{P d}(\mathrm{P}-\mathrm{P})\left[\mathrm{P}-\mathrm{P}=\operatorname{dppe}(\mathbf{9})\right.$, dppp (10)] [65] and $\mathrm{Cp}(\mathrm{CO})_{2} \mathbf{R e}=\mathrm{C}=\mathrm{CHPh}(\mathbf{1})$ [50] are also obtained in our experimental conditions. The processes induced by the chemical oxidation of clusters $\mathbf{7}$ and $\mathbf{8}$ by $[\mathrm{Fc}]\left[\mathrm{BF}_{4}\right]$ in different solvents are also studied by the EPR spectroscopy.

\section{Results and discussion}

The redox-properties of complexes 1-10 were investigated in acetonitrile solutions with $0.1 \mathrm{M}\left[\mathrm{Et}_{4} \mathrm{~N}\right]\left[\mathrm{BF}_{4}\right]$ as a supporting electrolyte using polarography at a dropping mercury electrode (DME), cyclic voltammetry at platinum and glassed carbon (GC) electrodes, and controlled-potential electrolysis at a Pt-electrode ${ }^{1}$. The electrochemical characteristics of these complexes are given in Table $1^{2}$.

\section{Binuclear complexes containing RePd metal cores}

The binuclear $\mu$-vinylidene complexes $\mathrm{Cp}(\mathrm{CO})_{2} \operatorname{RePd}(\mu-\mathrm{C}=\mathrm{CHPh})\left(\mathrm{PPh}_{3}\right)_{2} \quad$ (2) and $\mathrm{Cp}(\mathrm{CO})_{2} \operatorname{RePd}(\mu-\mathrm{C}=\mathrm{CHPh})(\mathrm{P}-\mathrm{P})[\mathrm{P}-\mathrm{P}=$ dppe (3), dppp (4)] in the acetonitrile solutions exhibit two one-electron oxidation stages at Pt and GC electrodes and two one-electron reduction stages at a dropping mercury electrode (Table 1). The cyclic voltamogramm of complex $\mathbf{4}$ at the CG electrode, apart from the two main oxidation waves, has the third small one at $0.62 \mathrm{~V}$ (peak $\mathrm{B}_{3}$ ) (or $0.54 \mathrm{~V}$ at the Pt electrode) (Fig. 1b).

${ }^{1}$ The application of different working electrodes offers an opportunity to study the oxidation and reduction properties of compounds in the extensive potential region. The measurement region of potentials in acetonitrile (vs. $\mathrm{Ag} / 0.1 \mathrm{M} \mathrm{AgNO}_{3}$ in $\mathrm{MeCN}$ ) is from 0.30 to $-3.20 \mathrm{~V}$ at DME , from 2.0 to $-2.2 \mathrm{~V}$, and from 2.0 to $-2.6 \mathrm{~V}$ at the $\mathrm{Pt}$ and GC electrodes, respectively.

${ }^{2}$ The dependence of the redox-potential values on the electrode nature is likely to be due to different absorptions of the complexes and their products on the electrode surface. 


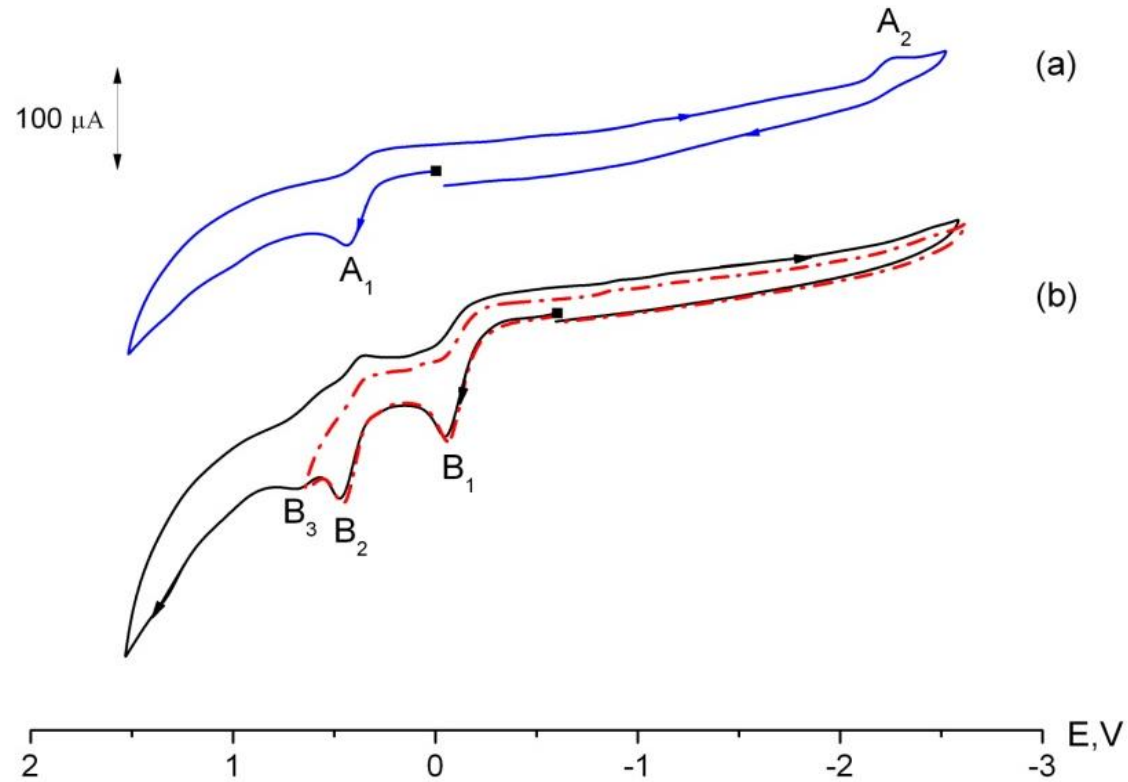

Fig. 1. Cyclic voltammograms of $\mathrm{Cp}(\mathrm{CO})_{2} \mathbf{R e}=\mathrm{C}=\mathrm{CHPh} \quad$ (1) (a), $\mathrm{Cp}(\mathrm{CO})_{2} \operatorname{RePd}(\mu-$ $\mathrm{C}=\mathrm{CHPh})(\mathrm{dppp})(\mathbf{4})(\mathrm{b})$ at $\mathrm{GC}$-electrode in $\mathrm{MeCN}\left(0.1 \mathrm{M} \mathrm{Et}_{4} \mathrm{NBF}_{4}, \mathrm{C}=2 \mathrm{MM}\right.$, scan rate $25 \mathrm{mV}$ $\mathrm{s}^{-1}$, potentials vs. $\mathrm{Ag} / 0.1 \mathrm{M} \mathrm{AgNO}_{3}$ in $\left.\mathrm{MeCN}\right)$.

In contrast to complex $\mathrm{Cp}(\mathrm{CO})_{2} \operatorname{RePd}(\mu-\mathrm{C}=\mathrm{CHPh})\left(\mathrm{PPh}_{3}\right)_{2}$ (2) the first oxidation and reduction potential values of $\mathbf{3}$ and $\mathbf{4}$ are shifted to the cathodic region, in accordance with the increase of the electron-donating properties of the chelate diphosphine dppe and dppp ligands (Table 1). However, the $E_{1 / 2}$ values of the oxidation and the reduction of complexes $\mathbf{3}$ and $\mathbf{4}$ are the same and don't depend on the nature of the dppe or dppp ligands (Table 1).

The half wave oxidation potential value of the second oxidation stage of 2-4 at the Ptand GC-electrodes coincides with the oxidation potential value $\left(E_{1 / 2}=0.33 \mathrm{~V}\right)$ of mononuclear complex 1 [58]. This demonstrates that the one-electron oxidation of the binuclear $\operatorname{RePd}$ complexes results in $\mathbf{1}$ in quantitative yield, which is clearly confirmed by the presence of two $v(\mathrm{CO})$ bands 1994 and $1920 \mathrm{~cm}^{-1}$, corresponding to $\mathrm{Cp}(\mathrm{CO})_{2} \mathrm{Re}=\mathrm{C}=\mathrm{CHPh}(\mathbf{1})$ in the IR spectra of the solutions obtained after the controlled-potential electrolysis of $\mathbf{2 - 4}$, or by the isolation of $\mathbf{1}$ in quantitative yields after the reactions of 2-4 with $[\mathrm{Fc}]\left[\mathrm{BF}_{4}\right]$. The third small oxidation wave of 4 (Fig. $2 b$, peak $\left.B_{3}\right)$ nearly coincides with the second oxidation wave of $\operatorname{Pd}(d p p p)_{2}\left(E_{1 / 2}=0.50\right.$ $\mathrm{V})$, indicating the formation of unstable Pd-containing fragments after the one-electron oxidation of 4. Hence, the one-electron oxidation of complexes 2-4 at the Pt- and GC-electrodes results in the cleavage of the $\mathrm{Re}-\mathrm{Pd}$ and $\mathrm{Pd}-\mathrm{C}$ bonds, to give the mononuclear vinylidene complex $\mathbf{1}$, and the following schemes of the redox reactions of the binuclear RePd complexes are to be proposed: 


$$
\begin{aligned}
& \mathrm{Cp}(\mathrm{CO})_{2} \operatorname{RePd}(\mu-\mathrm{C}=\mathrm{CHPh}) \mathrm{L} \stackrel{-\mathrm{e}^{-}}{\longrightarrow}\left[\mathrm{Cp}(\mathrm{CO})_{2} \operatorname{RePd}(\mu-\mathrm{C}=\mathrm{CHPh}) \mathrm{L}\right]^{+} \cdot \rightarrow \\
& \rightarrow \mathrm{Cp}(\mathrm{CO})_{2} \mathbf{R e}=\mathrm{C}=\mathrm{CHPh}+[\mathbf{P d L}]^{+} . \\
& \mathrm{Cp}(\mathrm{CO})_{2} \mathbf{R e}=\mathrm{C}=\mathrm{CHPh} \stackrel{-\mathrm{e}^{-}}{\longrightarrow}\left[\mathrm{Cp}(\mathrm{CO})_{2} \mathbf{R e}=\mathrm{C}=\mathrm{CHPh}\right]^{+} . \\
& {[\mathbf{P d L}]^{+} \stackrel{-\mathrm{e}^{-}}{\longrightarrow}[\mathbf{P d L}]^{2+} \quad \mathrm{L}=\left(\mathrm{PPh}_{3}\right)_{2}, \mathrm{dppe}, \mathrm{dppp}}
\end{aligned}
$$

\section{Complexes containing $\mathrm{ReFe}$ and $\mathrm{ReFe}_{2}$ metal cores}

The oxidation of the binuclear vinylidene complex $\mathrm{Cp}(\mathrm{CO})_{2} \operatorname{ReFe}(\mu-\mathrm{C}=\mathrm{CHPh})(\mathrm{CO})_{4}(\mathbf{5})$ at the Pt and GC electrodes occurs in two stages. The potential values of the latter are close enough to each other, which results in a collapse of two waves into one two-electron wave observed during the high rate scanning of the potential (Fig. 2a). The reduction of 5 at the GC and DME electrodes occurs in two one-electron stages, but only the one-electron reduction wave is observed at the Pt electrode. The cyclic voltammogram of complex $\mathbf{5}$ at the CG electrode is shown in Fig. 2a.

The cyclic voltammogram indicates that both the oxidation and reduction potential values of 5 are shifted to the anodic region as compared to binuclear complexes 2-4 (Table 1). The shift of the redox values results from the replacement of the fragment [PdL] with the $\sigma$ electron-donor ligands $\left(\mathrm{L}=\left(\mathrm{PPh}_{3}\right)_{2}\right.$, dppe, dppp) in complexes $\mathbf{2 - 4}$ by a fragment $\left[\mathrm{Fe}(\mathrm{CO})_{4}\right]$ containing $\pi$ electron-acceptor $\mathrm{CO}$ groups.

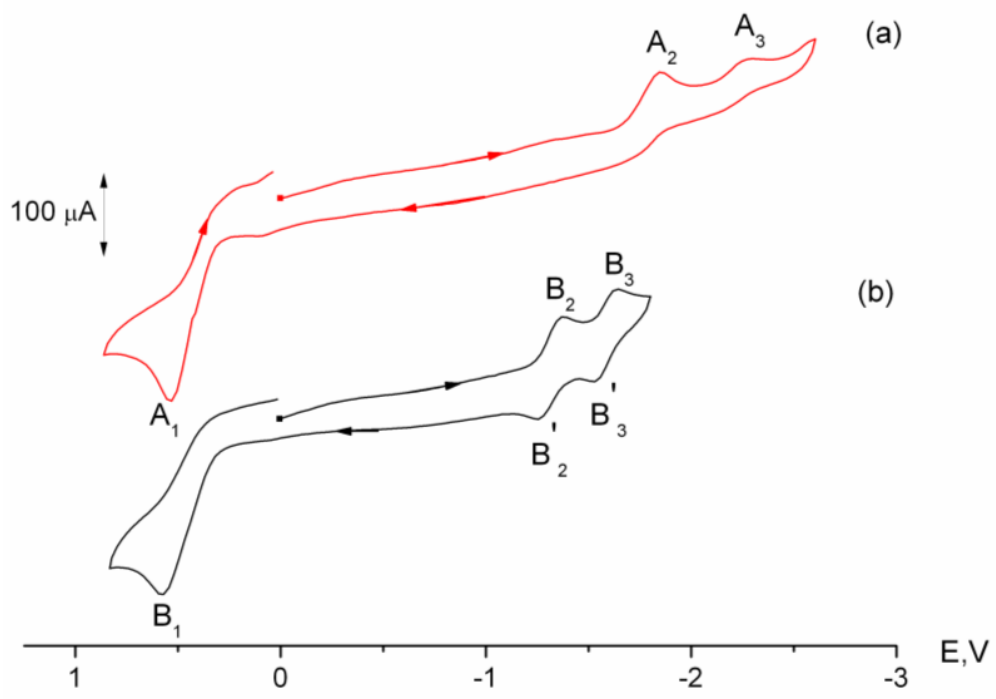

Fig. 2. Cyclic voltammograms of $\mathrm{Cp}(\mathrm{CO})_{2} \operatorname{ReFe}(\mu-\mathrm{C}=\mathrm{CHPh})(\mathrm{CO})_{4}(\mathbf{5})(a), \mathrm{Cp}(\mathrm{CO})_{2} \mathbf{R e F e}_{2}\left(\mu_{3^{-}}\right.$ $\mathrm{C}=\mathrm{CHPh})(\mathrm{CO})_{6}(\mathbf{6})(\mathrm{b})$ at the GC-electrode in $\mathrm{MeCN}\left(0.1 \mathrm{M} \mathrm{Et}_{4} \mathrm{NBF}_{4}, \mathrm{C}=2 \mathrm{MM}\right.$, scan rate 25 $\mathrm{mV} \mathrm{s}^{-1}$, potentials vs. $\mathrm{Ag} / 0.1 \mathrm{M} \mathrm{AgNO}_{3}$ in $\left.\mathrm{MeCN}\right)$. 
The potential value of the second one-electron oxidation wave of complex $\mathbf{5}$ at $\mathrm{E}_{1 / 2}=0.41$ $\mathrm{V}$ is close to that of the trinuclear cluster $\mathrm{Cp}(\mathrm{CO})_{2} \mathbf{R e F e}_{2}\left(\mu_{3}-\mathrm{C}=\mathrm{CHPh}\right)(\mathrm{CO})_{6}(\mathbf{6})$ (Table 1, Fig. 2) These data leads to an assumption that the electrochemical oxidation of $\mathbf{5}$ initially occurs similarly to that of complexes 2-4, resulting in the cleavage of the Re-Fe and Fe-C bonds and formation of Re-vinylidene complex $\mathbf{1}$ and an iron-carbonyl fragment. In doing so, the $\left[\mathbf{F e}(\mathrm{CO})_{4}\right]^{+}$. fragment is able to further react with unreacted complex $\mathbf{5}$, to give a radical cation $6^{+\bullet}:$

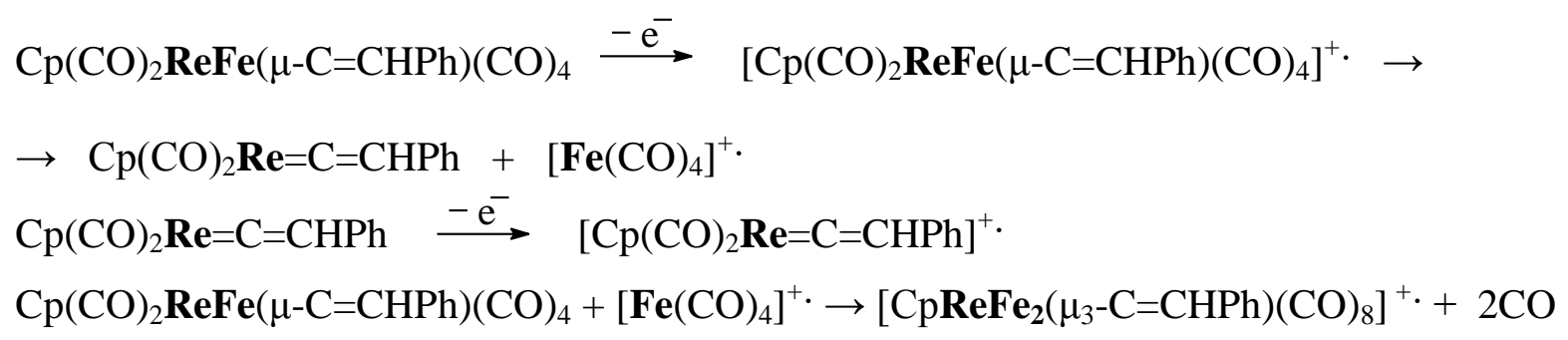

The interaction of the radical cation $\mathbf{6}^{+\bullet}$ with the iron fragment $\left[\mathrm{Fe}(\mathrm{CO})_{4}\right]^{+\cdot}$ results in the formation of neutral cluster $\mathbf{6}$ :

$\left[\mathrm{CpReFe}{ }_{2}\left(\mu_{3}-\mathrm{C}=\mathrm{CHPh}\right)(\mathrm{CO})_{8}\right]^{+} \cdot+\left[\mathbf{F e}(\mathrm{CO})_{4}\right]^{+} \cdot \rightarrow \mathrm{CpReFe}_{2}\left(\mu_{3}-\mathrm{C}=\mathrm{CHPh}\right)(\mathrm{CO})_{8}+\mathrm{Fe}^{2+}+4 \mathrm{CO}$

The controlled-potential electrolysis at the first oxidation wave of $\mathbf{5}$ with the following IR identification of the resulting solution confirmed the formation of the mononuclear vinylidene complex 1 ( $v(\mathrm{CO}): 1992$ and $\left.1916 \mathrm{~cm}^{-1}\right)$ and the trinuclear cluster $\mathrm{Cp}(\mathrm{CO})_{2} \mathbf{R e F e}_{2}\left(\mu_{3^{-}}\right.$ $\mathrm{C}=\mathrm{CHPh})(\mathrm{CO})_{6}(\mathbf{6})\left(2063,2020,1993,1958,1921,1874 \mathrm{~cm}^{-1}\right)$ after the one-electron oxidation of 5 . Moreover, the chemical oxidation of the solution of 5 by $\mathrm{AgBF}_{4} \cdot 3$ (dioxane) also resulted in the formation of compounds $\mathbf{1}$ and $\mathbf{6}$. Thus, the obtained results confirmed the scheme proposed above.

A cyclic voltammogram at the GC electrode of the cluster $\mathrm{Cp}(\mathrm{CO})_{2} \mathbf{R e F e}_{2}\left(\mu_{3^{-}}\right.$ $\mathrm{C}=\mathrm{CHPh})(\mathrm{CO})_{6}(\mathbf{6})$ is shown in Fig. 2b. The data in Table 1 indicate that the insertion of the second iron-carbonyl group into a molecule of $\mathbf{5}$ leads to a large anodic shift of the oxidation and, especially, reduction potentials of $\mathrm{CpReFe}_{2}\left(\mu_{3}-\mathrm{C}=\mathrm{CHPh}\right)(\mathrm{CO})_{8}(\mathbf{6})$ as compared to those of binuclear complexes $\mathbf{2 - 5}$. In contrast to complexes 5 and $\mathbf{2 - 4}$, the two-electron reduction processes of $\mathbf{6}$ are quasi-reversible ${ }^{3}$, indicating its great stability in redox-reactions.

\footnotetext{
${ }^{3}$ The ratio of the anodic to cathodic peak currents $\mathrm{I}_{\mathrm{pa}} / \mathrm{I}_{\mathrm{pc}} \sim 1\left(\mathrm{I}_{\mathrm{pa}}=22.90, \mathrm{I}_{\mathrm{pc}}=23.26\right.$ and $\left.\mathrm{I}_{\mathrm{pc}}=19.10, \mathrm{I}_{\mathrm{pa}}=20.0\right), \Delta \mathrm{E}=$ $\left|\mathrm{E}_{\mathrm{pc}}-\mathrm{E}_{\mathrm{pa}}\right|=112 \mathrm{mV}$ and $113 \mathrm{mV}$ (for the first and the second stages (Fig. 2b, peaks $\mathrm{B}_{2}, \mathrm{~B}_{2}$ and $\mathrm{B}_{3}, \mathrm{~B}_{3}$ ), which is in agreement with the quasi-reversible electron-transfer process [66]
} 


\section{Trinuclear clusters containing ReFePd metal cores}

The insertion of the third metal-containing fragment $\left[\mathrm{Fe}(\mathrm{CO})_{3}\right]$ into the binuclear complexes $\mathrm{Cp}(\mathrm{CO}){ }_{2} \operatorname{RePd}(\mu-\mathrm{C}=\mathrm{CHPh})(\mathrm{P}-\mathrm{P})[\mathrm{P}-\mathrm{P}=$ dppe (3), dppp (4)] led to the formation of the trinuclear $\mu_{3}$-vinylidene clusters $\mathrm{CpReFePd}\left(\mu_{3}-\mathrm{C}=\mathrm{CHPh}\right)(\mathrm{CO})_{2}(\mathrm{P}-\mathrm{P})[\mathrm{P}-\mathrm{P}=$ dppe (7), dppp (8)]. Their molecular structures were proposed based on IR, NMR spectroscopic and elemental analysis data [64], but their exact structures weren't obtained. In this work monocrystals of cluster $\left[\mathrm{CpReFePd}\left(\mu_{3}-\mathrm{C}=\mathrm{CHPh}\right)(\mathrm{CO})_{5}(\mathrm{dppe})\right](7)$ of the appropriate quality were obtained to fill this gap.

The molecular structure, selected bond lengths and angles of cluster 7 are presented in Figure 3. The crystal data, data collection and structure refinement details are summarized in Table 2.

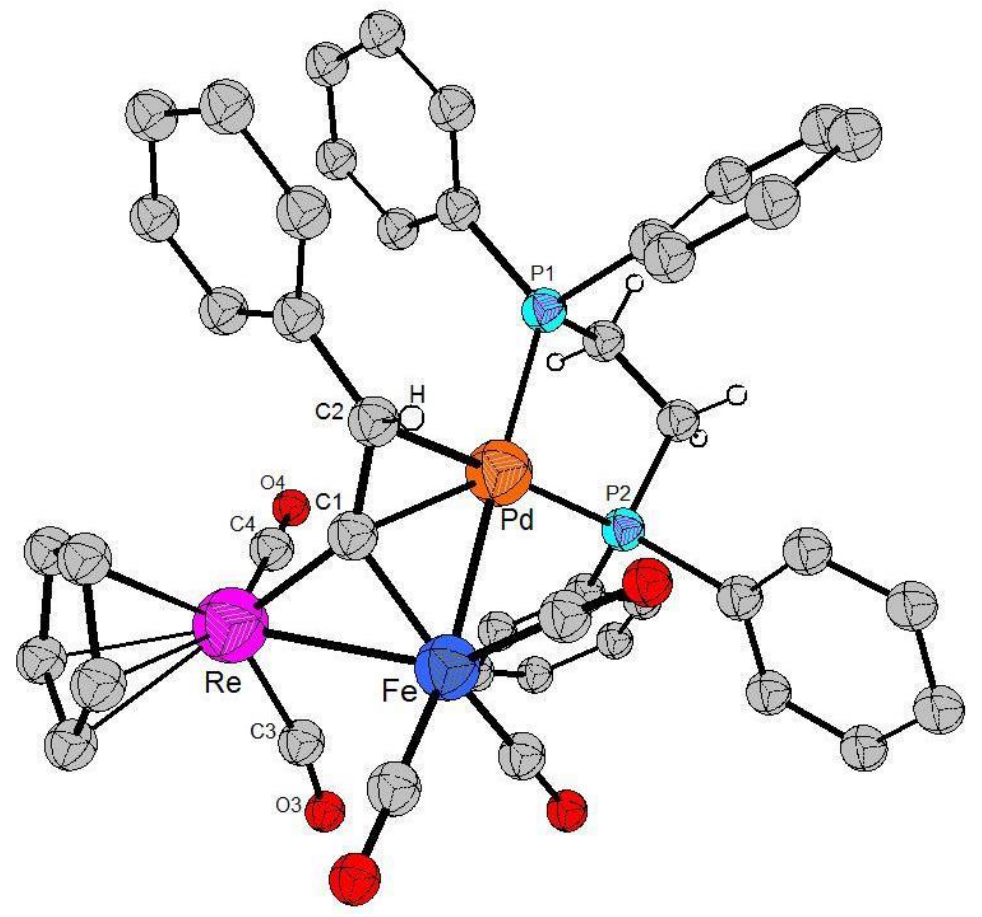

Fig. 3. Perspective view of cluster $\left[\mathrm{CpReFePd}\left(\mu_{3}-\mathrm{C}=\mathrm{CHPh}\right)(\mathrm{CO})_{5}(\mathrm{dppe})\right](7)$. Hydrogen atoms and the $\mathrm{MeCN}$ molecule are omitted for clarity. The selected interatomic distances $(\AA)$ and bond angles (deg): $\mathrm{Re}-\mathrm{Fe}=2.7791(4), \mathrm{Fe}-\mathrm{Pd}=2.6393(4), \mathrm{Re} \cdots \mathrm{Pd}=3.764, \mathrm{Re}-\mathrm{C} 1=2.066(2), \mathrm{Fe}-\mathrm{C} 1=1.875(2), \mathrm{C} 1=\mathrm{C} 2=$ 1.403(3), Pd-C1 = 2.226(2), Pd-C2 = 2.241(2), Pd-P1 = 2.3035(7), Pd-P2 = 2.2926(6), Re-C3 = 1.915(3), $\mathrm{Re}-\mathrm{C} 4=1.878(3), \mathrm{C} 3-\mathrm{O} 3=1.168(3), \mathrm{C} 4-\mathrm{O} 4=1.164(3)$; Re-Fe-Pd = 87.948(11), Pd-Re-Fe 44.49, Fe$\mathrm{Pd}-\mathrm{Re}=47.56, \mathrm{Re}-\mathrm{C} 1-\mathrm{C} 2=139.77(18), \mathrm{Fe}-\mathrm{C} 1-\mathrm{C} 2=130.66(18), \mathrm{Pd}-\mathrm{C} 1-\mathrm{C} 2=72.25(13), \mathrm{Pd}-\mathrm{C} 2-\mathrm{C} 1=$ 71.15(12), C1-Pd-C2 = 36.60(9), P1-Pd-P1 = 86.15(2), C2-Pd-Fe = 74.94(6), Re-C3-O3 = 168.6(2), Re$\mathrm{C} 4-\mathrm{O} 4=178.3(2)$

The cluster core consists of rhenium, iron and palladium atoms. The Re-Fe and $\mathrm{Fe}-\mathrm{Pd}$ bond lengths are 2.7791(4) and 2.6393(4) $\AA$, respectively. The bond angles ReFePd, PdReFe, and FePdRe are $87.948(11), 44.49$, and $47.56^{\circ}$, respectively. The Re $\cdots P d$ distance of $3.764 \AA$ is nonbonding, which is by approximately $0.8 \AA$ longer than the sum of the covalent radii of the $\operatorname{Re}$ and Pd atoms [67] and, moreover, exceed all the known Re-Pd bond distances. Thus, the metal core of the cluster should be regarded as a ReFePd chain. The phenylvinylidene ligand is 
coordinated to the ReFePd core in a $\mu_{3}-\eta^{2}: \eta^{1}: \eta^{1}$ fashion, forming $\sigma$-bonds with two adjacent iron and rhenium atoms and a $\pi$-bond with a palladium atom. The $\mathrm{Re}-\mathrm{C} 1$ and $\mathrm{Fe}-\mathrm{C} 1$ bond distances are 2.066(2) and 1.875(2). The length of the $\mathrm{C} 1=\mathrm{C} 2$ bond is 1.403(3) $\AA$, which is similar to that found in the trinuclear clusters with the $\mu_{3}$-phenylvinylidene ligand $[34,33]$. The $\mathrm{Pd}-\mathrm{C} 1$ and $\mathrm{Pd}-$ C2 bond distances of 2.226(2) and 2.241(2) $\AA$ are approximately equal. The palladium atom is coordinated by two phosphorus of 1,2-bis(diphenylphosphino)ethane ligand, the P1-Pd-P2 angle is $86.15(2)^{\circ}$. At the same time, the $\mathrm{C} 2$ atom of vinylidene and iron atom of the metal core form a $\mathrm{C} 2-\mathrm{Pd}-\mathrm{Fe}$ angle of $74.94(6)^{\circ}$. The value of the P1-Pd-P2 and C2-Pd-Fe angles indicate a square planar configuration around the palladium atom. The most remarkable feature of the $\mathrm{ReFePd}$ cluster structure is the symmetrical $\pi$-coordination of the $\mu_{3}-\mathrm{C} 1=\mathrm{C} 2 \mathrm{HPh}$ ligand to the palladium atom. Thus, the difference $\Delta \mathrm{d}$ between the Pd-C1 and Pd-C2 bonds is only $0.015 \AA$; the Pd-C1$\mathrm{C} 2$ and $\mathrm{Pd}-\mathrm{C} 2-\mathrm{C} 1$ bond angles are $72.25(13)$ and $71.15(12)^{\circ}$, respectively. In the previously characterized $\mu_{3}$-vinylidene $\mathrm{ReFePt}$ clusters $\left(\mathrm{CpReFePt}\left(\mu_{3}-\mathrm{C}=\mathrm{CHPh}\right)(\mathrm{CO})_{6} \mathrm{PPh}_{3}\right.$ and $\left.\mathrm{CpReFePt}\left(\mu_{3}-\mathrm{C}=\mathrm{CHPh}\right)(\mathrm{CO})_{5}\left[\mathrm{P}\left(\mathrm{OPr}^{\mathrm{i}}\right)_{3}\right]_{2}\right)$ the $\mu_{3}-\mathrm{C} 1=\mathrm{C} 2 \mathrm{HPh}$ ligand was $\eta^{1}$-bound to the terminal Re and $\mathrm{Pt}$ atoms and asymmetrically $\eta^{2}$-coordinated to the central $\mathrm{Fe}$ atom $[40,68]$, for which the difference $\Delta \mathrm{d}$ between the $\mathrm{Fe}-\mathrm{C} 1$ and $\mathrm{Fe}-\mathrm{C} 2$ bonds is approximately $0.2 \AA$; the $\mathrm{Fe}-$ $\mathrm{C}(1)-\mathrm{C}(2)$ and $\mathrm{Fe}-\mathrm{C}(2)-\mathrm{C}(1)$ angles are $80.72(42)^{\circ}$ and $60.47(37)^{\circ}$, respectively. Previously, the symmetrical $\eta^{2}$-bonding of $\mu_{3}$-vinylidene ligands in trimetallic clusters is observed for the compounds $\mathrm{CpMnFePt}\left(\mu_{3}-\mathrm{C}=\mathrm{CHPh}\right)(\mathrm{CO})_{6}\left[\eta^{1}-\mathrm{Ph}_{2} \mathrm{PCH}_{2} \mathrm{P}(=\mathrm{O}) \mathrm{Ph}_{2}\right]$ and $\left(i-\mathrm{Pr}_{3} \mathrm{P}\right) \mathrm{RhFe}_{2}\left(\mu_{3^{-}}\right.$ $\left.\mathrm{C}^{1}=\mathrm{C}^{2} \mathrm{H}_{2}\right)(\mu-\mathrm{CO})_{2}(\mathrm{CO})_{4} \mathrm{Cp}[69,41]$.

Compound 7 is a representative example of the heterotrimetallic cluster containing the coordinated vinylidene ligand in the $\mu_{3}-\eta^{2}: \eta^{1}: \eta^{1}$ mode $[34,33]$. However, the ReFePd metal core makes this cluster unique because the previous examples of the structurally characterized clusters containing together rhenium, iron and palladium atoms were not reported.

Table 2

Crystal data and $\mathrm{X}$-ray experimental details for complex 7

\begin{tabular}{|l|l|}
\hline Empirical formula & $\mathrm{C}_{44} \mathrm{H}_{35} \mathrm{O}_{5} \mathrm{P}_{2} \mathrm{FeRePd} \cdot\left(\mathrm{C}_{2} \mathrm{H}_{3} \mathrm{~N}\right)$ \\
\hline Formula weight & 1095.16 \\
\hline Temperature/K & 150.0 \\
\hline Crystal system & triclinic \\
\hline Space group & $P-1$ \\
\hline $\mathrm{a} / \AA$ & $10.4810(3)$ \\
\hline $\mathrm{b} / \AA$ & $12.1833(4)$ \\
$\mathrm{c} / \AA$ & $17.3433(6)$ \\
\hline$\alpha{ }^{\circ}$ & $103.6066(11)$ \\
\hline$\beta /{ }^{\circ}$ & $92.8317(12)$ \\
\hline$\gamma /{ }^{\circ}$ & $102.5985(11)$ \\
\hline Volume/ $\AA^{3}$ & $2088.76(12)$ \\
\hline $\mathrm{Z}$ & 2 \\
\hline $\mathrm{d}_{\text {calc }} /\left(\mathrm{g} \cdot \mathrm{cm}^{-3}\right)$ & 1.741 \\
\hline$\mu / \mathrm{mm}^{-1}$ & 3.783 \\
\hline $\mathrm{F}(000)$ & 1076.0 \\
\hline Crystal size/mm & \\
\hline Radiation & $0.2 \times 0.2 \times 0.15$ \\
\hline $2 \Theta$ range for data collection/ & 2.43 to 61.924 \\
\hline Index ranges & $-8 \leq \mathrm{h} \leq 15,-17 \leq \mathrm{k} \leq 17,-23 \leq 1 \leq 24$ \\
\hline Reflections collected & 23612 \\
\hline
\end{tabular}




\begin{tabular}{|l|l|}
\hline Independent reflections & $11339\left[\mathrm{R}_{\text {int }}=0.0231, \mathrm{R}_{\text {sigma }}=0.0362\right]$ \\
\hline Data/restraints/parameters & $11339 / 0 / 515$ \\
\hline Goodness-of-fit on $\mathrm{F}^{2}$ & 1.034 \\
\hline Final R indexes $[\mathrm{I}>=2 \sigma(\mathrm{I})]$ & $\mathrm{R}_{1}=0.0253, \mathrm{wR}_{2}=0.0499$ \\
\hline Final R indexes [all data] & $\mathrm{R}_{1}=0.0323, \mathrm{wR}_{2}=0.0519$ \\
\hline$\Delta \rho_{\min } / \Delta \rho_{\max }\left(\mathrm{e} / \AA^{3}\right)$ & $1.12 /-0.68$ \\
\hline
\end{tabular}

As compared to the oxidation and reduction values of binuclear complexes $\mathbf{3}$ and $\mathbf{4}$, those of the ReFePd clusters are shifted to the more negative and positive regions, respectively (Table 1). These data reflects the narrowing of the HOMO-LUMO energy gap of these clusters caused by the introduction of the $\left[\mathrm{Fe}(\mathrm{CO})_{3}\right]$ fragment into 3 and $\mathbf{4}$. Thus, the nature of the chelate diphosphine ligands dppe and dppp at the palladium atom affects the redox potential values of 7 and 8 in contrast to complexes 3 and 4 (Table 1). The cyclic voltammograms of the ReFePd clusters at the CG electrode are shown in Fig. 4.

The two first oxidation waves of the clusters were found to be different in their ratios of the wave heights: 5:1 for 7 (Fig. 4a, the peak A1 and A2) and 1:1 for 8 (Fig. 4b, the peak B1 and B2). The sums of these waves yield a one-electron wave (Table 1). These features apparently indicate the presence of two isomers in the solutions of the ReFePd clusters [70] which were previously shown by the NMR study [64].

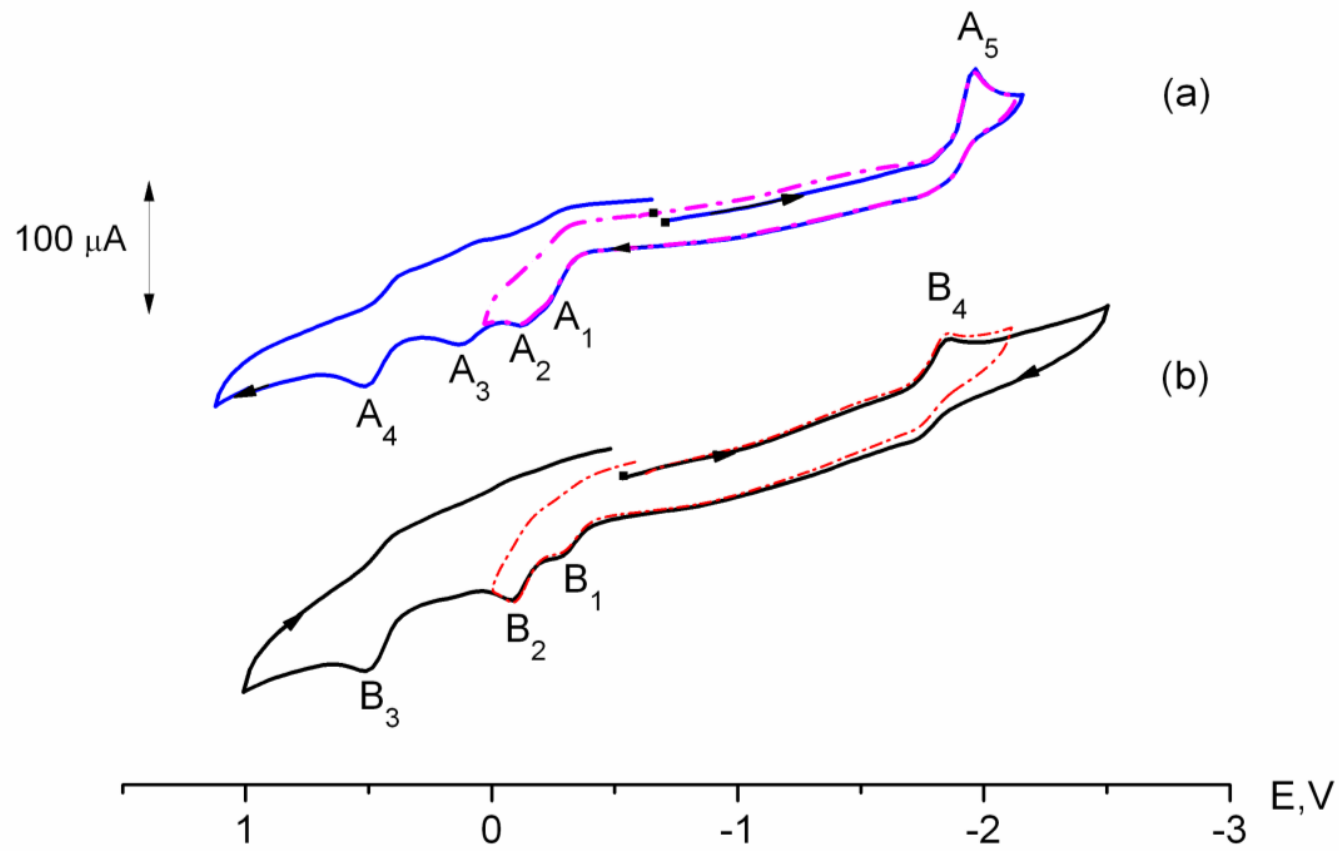

Fig. 4. Cyclic voltammograms of $\mathrm{CpReFePd}\left(\mu_{3}-\mathrm{C}=\mathrm{CHPh}\right)(\mathrm{CO})_{5}(\mathrm{dppe})(7)(\mathrm{a}), \mathrm{CpReFePd}\left(\mu_{3^{-}}\right.$ $\mathrm{C}=\mathrm{CHPh})(\mathrm{CO})_{5}(\mathrm{dppp})(8)(\mathrm{b})$ at $\mathrm{GC}$-electrode in $\mathrm{MeCN}\left(0.1 \mathrm{M} \mathrm{Et}_{4} \mathrm{NBF}_{4}, \mathrm{C}=2 \mathrm{MM}\right.$, scan rate $25 \mathrm{mV} \mathrm{s}^{-1}$, potentials vs. $\mathrm{Ag} / 0.1 \mathrm{M} \mathrm{AgNO}_{3}$ in $\mathrm{MeCN}$ ). 
The one-electron oxidation processes of $\mathbf{7}$ and $\mathbf{8}$ lead to unstable radical cations $\left[\mathrm{CpReFePd}\left(\mu_{3}-\mathrm{C}=\mathrm{CHPh}\right)(\mathrm{CO})_{5}(\mathrm{P}-\mathrm{P})\right]^{+\bullet}\left(\mathrm{P}-\mathrm{P}=\operatorname{dppe}\left(\mathbf{7}^{+\bullet}\right), \operatorname{dppp}\left(\mathbf{8}^{+\bullet}\right)\right)$ :

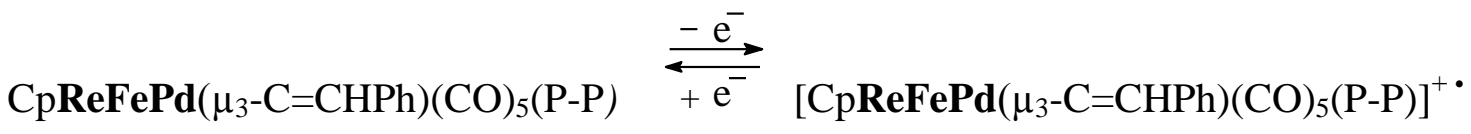

The potential values of the second one-electron oxidation waves of $\mathbf{8}$ at the Pt electrode and those of clusters 7, 8 at the GC electrode are close to $E_{1 / 2}$ of the binuclear RePd complex oxidation. The potential values of the fourth oxidation wave of $\mathbf{7}$ at the $\mathrm{Pt}$ and GC electrodes (Table 1) and the third oxidation wave of $\mathbf{8}$ at the GC electrode are close to the potential values of the second oxidation wave of $\mathrm{CpReFe}_{2}\left(\mu_{3}-\mathrm{C}=\mathrm{CHPh}\right)(\mathrm{CO})_{8}(\mathbf{6})$ (Table 1). These data allowed to propose an electrochemical oxidation mechanism of the clusters:

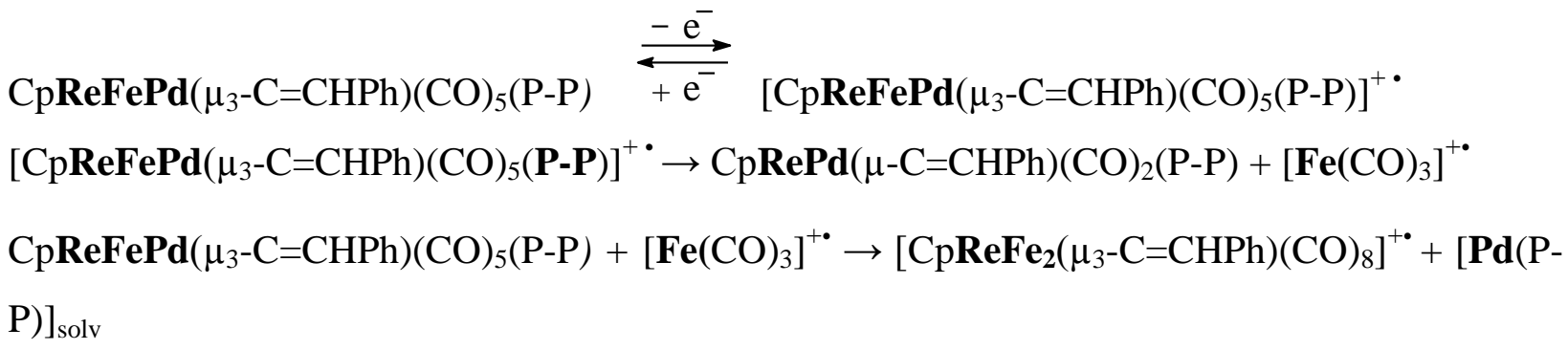

However, the IR spectra of the solutions obtained by 1 hour controlled-potential electrolysis at the first oxidation wave of clusters $\mathbf{7}$ and $\mathbf{8}$ showed carbonyl stretching frequencies of the complexes $\mathrm{Cp}(\mathrm{CO})_{2} \mathbf{R e}=\mathrm{C}=\mathrm{CHPh}\left(v(\mathrm{CO}): 1992\right.$ и $\left.1916 \mathrm{~cm}^{-1}\right)$ and $(\mathrm{CO})_{8} \mathbf{F e} \mathbf{e}_{2} \mathbf{P d}(\mathrm{P}-\mathrm{P})[\mathrm{P}-\mathrm{P}=$ dppe, dppp] (P-P = dppe, v(CO): 2052 s. 2002 v.s, 1969 s, 1955 s, 1909 w.br $\left(\mathrm{CH}_{2} \mathrm{Cl}_{2}\right)$; P-P = dppp, v(CO): 2049 s. 2000 v.s, 1964 s, 1945 sh, 1885 w.br $\left.\left(\mathrm{CH}_{2} \mathrm{Cl}_{2}\right)\right)$ [50, 65]. The chemical oxidation of the ReFePd clusters by $\left[\mathrm{Fc}_{3}\right]\left[\mathrm{BF}_{4}\right]$ gave the same results, mononuclear vinylidene complex 1 and triangular clusters $\mathbf{P d F e}$ were obtained with 54 and $39 \%$ and 53 and $41 \%$ yields for clusters $\mathbf{7}$ and $\mathbf{8}$, respectively. The obtained results are indicative of the transformations of the electrochemically obtained intermediate oxidation products of $\mathbf{7}$ and $\mathbf{8}$ into more stable triangular clusters $(\mathrm{CO})_{8} \mathbf{F e}_{2} \mathbf{P d}(\mathrm{P}-\mathrm{P})\left[\mathrm{P}-\mathrm{P}=\right.$ dppe (9), dppp (10)] and complex $\mathrm{Cp}(\mathrm{CO})_{2} \mathbf{R e}=\mathrm{C}=\mathrm{CHPh}(\mathbf{1})$ with time:

$\mathrm{CpRePd}(\mu-\mathrm{C}=\mathrm{CHPh})(\mathrm{CO})_{2}(\mathrm{P}-\mathrm{P})+\left[\mathrm{CpReFe}_{2}\left(\mu_{3}-\mathrm{C}=\mathrm{CHPh}\right)(\mathrm{CO})_{8}\right]^{+\bullet} \rightarrow 2 \mathrm{Cp}(\mathrm{CO})_{2} \mathbf{R e}=\mathrm{C}=\mathrm{CHPh}$ $+\left[(\mathrm{CO})_{6} \mathbf{F e}_{2} \mathbf{P d}(\mathrm{P}-\mathrm{P})\right]^{+\bullet}$

$$
\left[(\mathrm{CO})_{6} \mathbf{F e}_{2} \mathbf{P d}(\mathrm{P}-\mathrm{P})\right]^{+\bullet}+\left[\mathrm{Fe}(\mathrm{CO})_{3}\right]^{+\bullet} \rightarrow(\mathrm{CO})_{8} \mathrm{Fe}_{2} \mathbf{P d}(\mathrm{P}-\mathrm{P})+\mathbf{F e}^{2+}+\mathrm{CO}
$$

EPR experiments were performed in order to exactly define the oxidation mechanisms of the $\mathrm{ReFePd}$ clusters and study their radical cations $\mathbf{7}^{+\bullet}$ and $\mathbf{8}^{+\bullet}$. For these purposes, $1 \mathrm{mM}$ solutions of the clusters were treated with $1 \mathrm{mM}$ solution of $[\mathrm{Fc}]\left[\mathrm{BF}_{4}\right]$ in $\mathrm{CH}_{2} \mathrm{Cl}_{2}$ at room 
temperature. Before transferring in quartz tubes and freezing in liquid nitrogen, three samples were collected from the reaction mixture with the delay times of 2.5 minutes (sample 1), 7.5 minutes (sample 2) and 12.5 minutes (sample 3).

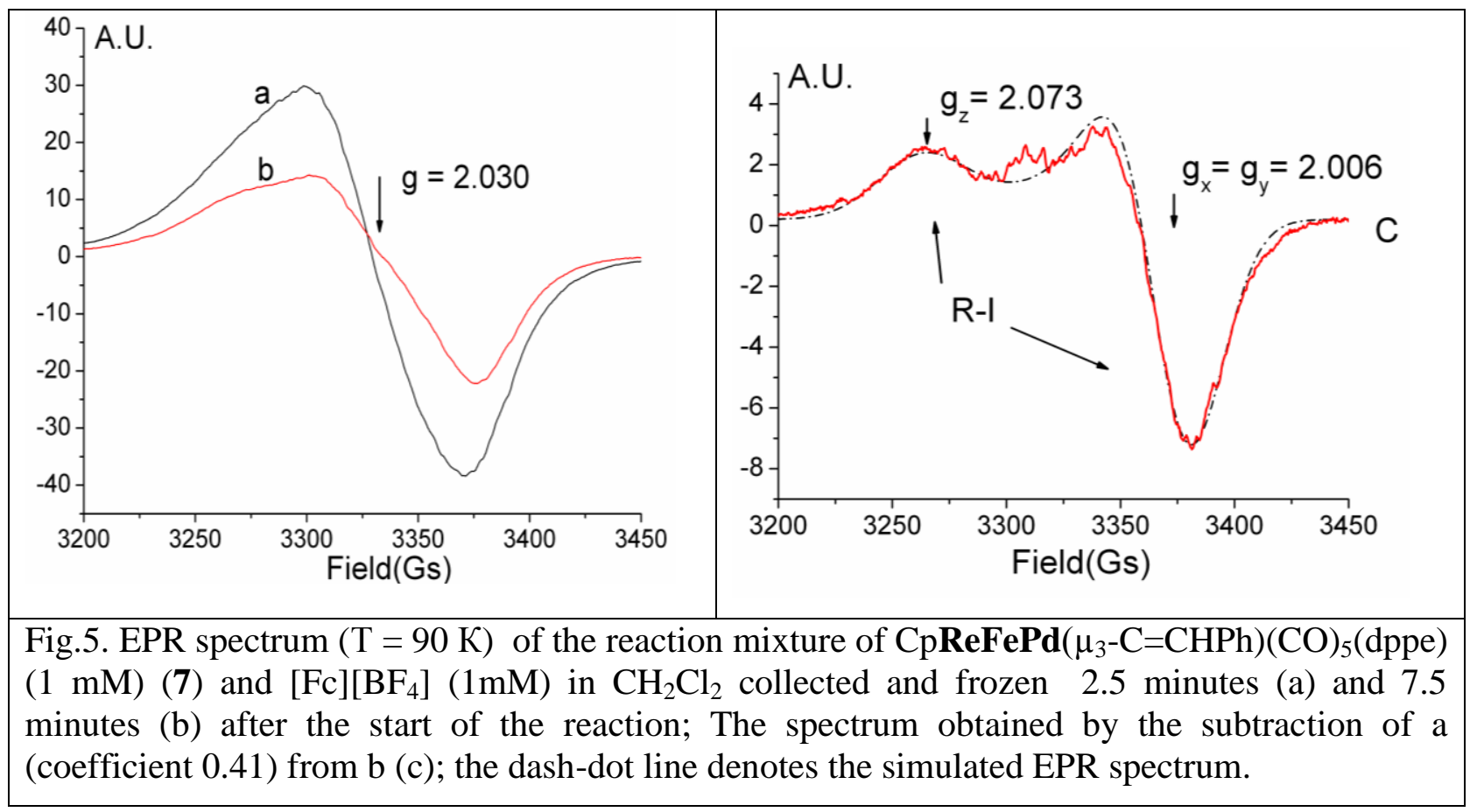

The EPR spectrum of sample 1 of cluster $\mathbf{7}$ shows an intense partially anisotropic signal at $\mathrm{g}_{0}=2.030$ (Fig.5, spectrum a). For sample 2 of $\mathbf{7}$ in the EPR spectrum the decrease of the intensity and change of the shape of the signals are observed, which is indicative of further transformation of the radical cation $\mathbf{7}^{+\bullet}$ (Fig.5, spectrum b). The subtraction of the spectrum $a$ from spectrum $b$ results in the transition with an axial anisotropy $\left(\mathrm{g}_{\mathrm{II}}=2.073, \mathrm{~g}_{\perp}=2.006\right)$ (Fig.5, spectrum c; R-I). The EPR spectrum of sample 3 contains a lower intensity signal caused by the presence of paramagnetic axial centers R-I and other centers with rhombic anisotropy of the g-tensor R-II (Fig.6b, the parameters of R-II are $\mathrm{g}_{\mathrm{z}}=2.075, \mathrm{~g}_{\mathrm{y}}=2.0385, \mathrm{~g}_{\mathrm{x}}=2.006$ ). 

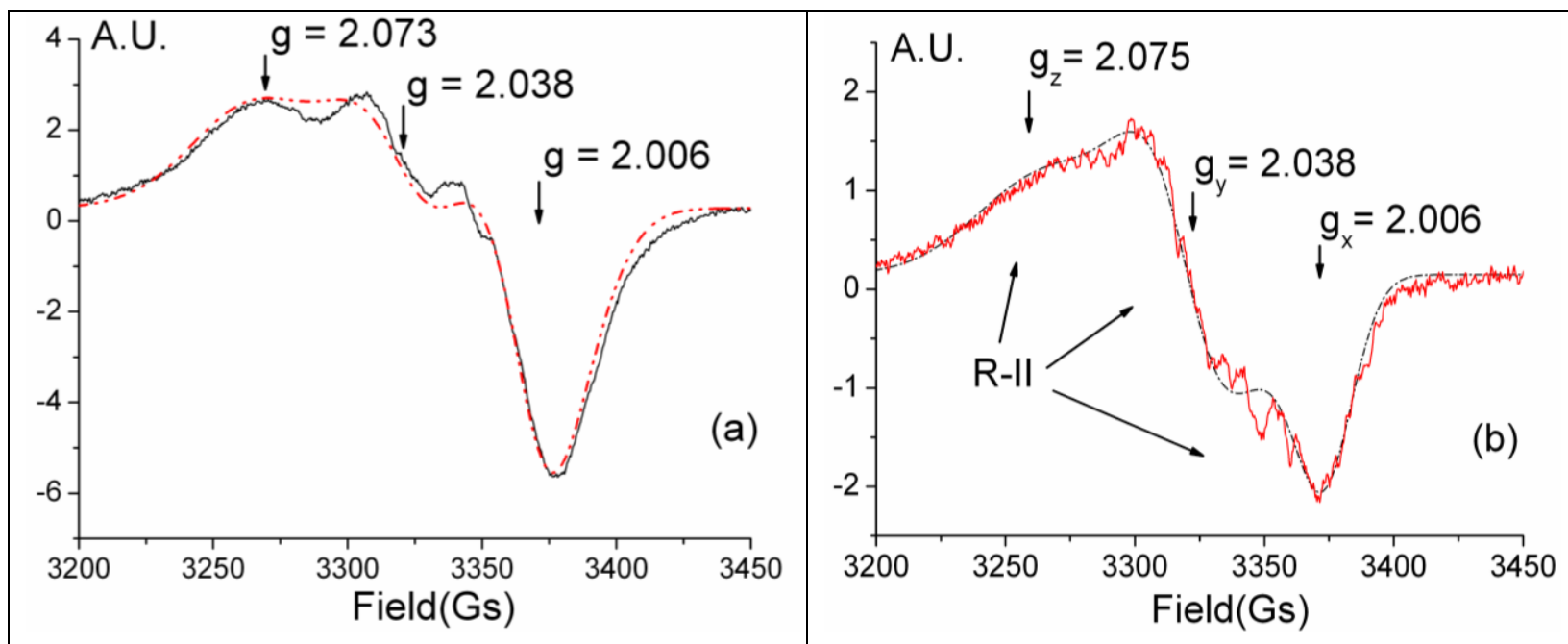

Fig.6. EPR spectrum $(\mathrm{T}=90 \mathrm{~K})$ of the reaction mixture of $\mathrm{CpReFePd}\left(\mu_{3}-\mathrm{C}=\mathrm{CHPh}\right)(\mathrm{CO})_{5}(\mathrm{dppe})$ $(1 \mathrm{mM})(7)$ and $[\mathrm{Fc}]\left[\mathrm{BF}_{4}\right](1 \mathrm{mM})$ in $\mathrm{CH}_{2} \mathrm{Cl}_{2}$ collected and frozen 12.5 minutes (the solid line) after the start of the reaction; the simulated EPR spectrum as a superposition of the axial and rhombic signals (the dash-dot line) (a); the EPR spectrum obtained by the subtraction of Fig.5b from Fig.6a (solid line); the dash-dot line denotes the simulated EPR spectrum of the rombic centers R-II.

The presence of the signal close to the symmetric one in the EPR spectrum of sample 1 can be explained by the formation of $\mathbf{7}^{+\bullet}$, which eventually evolves in the paramagnetic centers R-I and R-II (sample 2 and sample 3). The variations of the reactant concentrations (initial cluster 7 and $[\mathrm{Fc}]\left[\mathrm{BF}_{4}\right]$ ), temperature and solvents made it possible to observe a relatively resolved hyperfine structure in the EPR spectrum (Fig.7a).
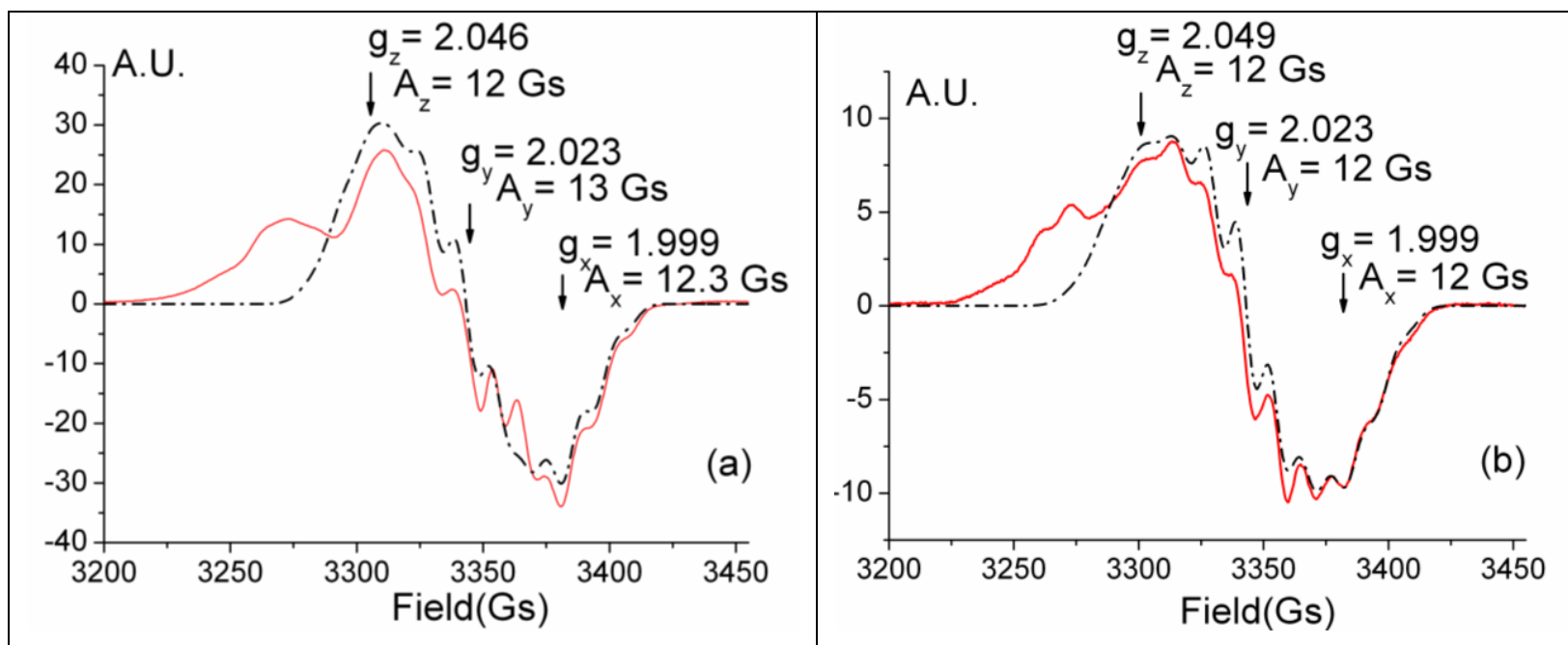

Fig.7. EPR spectrum $(\mathrm{T}=90 \mathrm{~K})$ of the reaction mixture of $\mathrm{Cp} \operatorname{ReFePd}\left(\mu_{3}-\mathrm{C}=\mathrm{CHPh}\right)(\mathrm{CO})_{5}(\mathrm{dppe})$ (7) (a is the solid line) and $\mathrm{Cp} \operatorname{ReFePd}\left(\mu_{3}-\mathrm{C}=\mathrm{CHPh}\right)(\mathrm{CO})_{5}(\mathrm{dppp})(\mathbf{8})(\mathrm{b}$ is the solid line) (1 mM) and $[\mathrm{Fc}]\left[\mathrm{BF}_{4}\right](0.1 \mathrm{mM})$ in the solution of $\mathrm{CCl}_{4}$ and $\mathrm{CHCl}_{3}(1: 1)$ collected and frozen 2 minutes after the start of the reaction; the simulated EPR spectra (the dash dot line). 
The agreement between the simulated and experimental spectra of $\mathbf{7}^{+\bullet}$ (Fig.7a) shows that its hyperfine structure is determined by the interaction of four equivalent nuclei $(I=1 / 2)$ with an unpaired electron of the rhombic paramagnetic center $\left(\mathrm{g}_{\mathrm{x}}=1.9998, \mathrm{~A}_{\mathrm{x}}=12.3 \mathrm{Gs}, \mathrm{g}_{\mathrm{y}}=2.0228\right.$, $\mathrm{A}_{\mathrm{y}}=13 \mathrm{Gs}, \mathrm{g}_{\mathrm{z}}=2.046, \mathrm{~A}_{\mathrm{z}}=12 \mathrm{Gs}$ ). A closer agreement of the experimental and simulated spectra was obtained for the high-field part of the EPR spectrum, and a less precise agreement of the spectra was observed for the low-field part due to the additional contributions from the radical centers R-I and R-II. The presence of four-equivalent nuclei in the paramagnetic center can be attributed to the localization of the spin density $(\leq 0.3 \%)$ on a highly symmetrical counter anion $\left[\mathrm{BF}_{4}\right]^{-}$, the equivalence of its fluorine nuclei can be explained by their internal rotation. Although one may expect the localization of the unpaired spin to the rhenium or palladium atoms, the hyperfine structure at the rhenium, palladium, or phosphorus nuclei is not observed beyond $\Delta H \approx 5 \mathrm{Gs}$ [71], so the unpaired electron is seen to be mainly localized on the iron atom of the radical cation $\mathbf{7}^{+\bullet}[72]$ :

$\mathrm{CpReFePd}\left(\mu_{3}-\mathrm{C}=\mathrm{CHPh}\right)(\mathrm{CO})_{5}(\mathrm{P}-\mathrm{P})+[\mathrm{Fc}]\left[\mathrm{BF}_{4}\right] \rightarrow\left\{\left[\mathrm{CpReFePd}\left(\mu_{3}-\mathrm{C}=\mathrm{CHPh}\right)(\mathrm{CO})_{5}(\mathrm{P}-\right.\right.$ $\left.\mathrm{P})]\left[\mathrm{BF}_{4}\right]\right\}^{\bullet}+\mathrm{Cp}_{2} \mathrm{Fe}$

The increase of the additional axial signal R-I is caused by the decomposition of the initial paramagnetic complex ${7^{+\cdot}}^{\circ}$ and formation of the radical center with the high symmetry axis with time:

$\left\{\left[\mathrm{CpReFePd}\left(\mu_{3}-\mathrm{C}=\mathrm{CHPh}\right)(\mathrm{CO})_{5}(\mathrm{P}-\mathrm{P})\right]\left[\mathrm{BF}_{4}\right]\right\}^{\bullet} \rightarrow\left[\mathrm{CpRePd}(\mu-\mathrm{C}=\mathrm{CHPh})(\mathrm{CO})_{2}(\mathrm{P}-\mathrm{P})\right]+$ $\left\{\left[\mathrm{Fe}(\mathrm{CO})_{3}\right]\left[\mathrm{BF}_{4}\right]\right\}^{\bullet}$

The interaction between the initial ReFePd cluster 7 and paramagnetic center R-I gives rise to the formation of the radical rhombic center R-II:

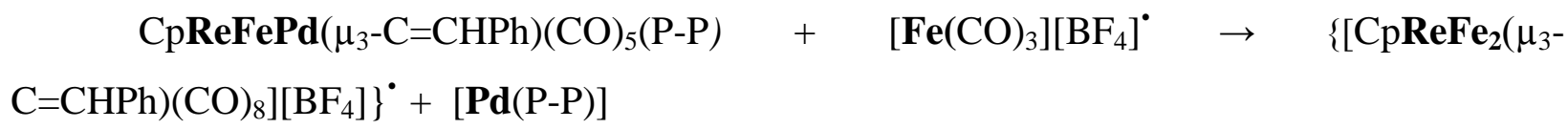

The intensities of the signals in the EPR spectra of the samples decrease with time, to indicate the recombination of the formed radical cations into diamagnetic products according to the suggested schemes of the electrochemical oxidation of cluster 7 (see above).

The EPR spectra of the radical cation $\mathbf{8}^{+\bullet}$ samples also contain several types of paramagnetic species but the concentration of the additional radical centers is considerably lower (Fig.7b), which indicates longer life-time of the radical cation $\mathbf{8}^{+\bullet}$ as compared with $\mathbf{7}^{+\bullet}$. In the EPR spectra of $\mathbf{8}^{+\bullet}$ the presence of the hyperfine structure of the four-equivalent nuclei $(I=1 / 2)$ is also observed. However, there are small differences between $\mathbf{8}^{+\bullet}$ and $\mathbf{7}^{+\boldsymbol{\bullet}}$ in the values of the hyperfine structure constants and $\mathrm{g}_{\mathrm{z}}\left(\mathrm{g}_{\mathrm{x}}=1.9989, \mathrm{~g}_{\mathrm{y}}=2.023, \mathrm{~g}_{\mathrm{z}}=2.049, \mathrm{~A}_{\mathrm{x}}=\mathrm{A}_{\mathrm{y}}=\mathrm{A}_{\mathrm{z}}=12 \mathrm{Gs}\right)$, which indicates the absence of the hyperfine structure anisotropy in $\mathbf{8}^{+\cdot}$ and weak interaction of the counter ion $\left[\mathrm{BF}_{4}\right]^{-}$and radical cation $\mathbf{8}^{+\bullet}$. 
Thus, the EPR study of the radical cations $\mathbf{7}^{+\bullet}$ and $\mathbf{8}^{+\bullet}$ confirms their initial decomposition to binuclear complexes $\mathrm{Cp}(\mathrm{CO})_{2} \operatorname{RePd}(\mu-\mathrm{C}=\mathrm{CHPh})(\mathrm{P}-\mathrm{P})[\mathrm{P}-\mathrm{P}=$ dppe $(\mathbf{3})$, dppp (4)] and a fragment $\left[\mathrm{Fe}(\mathrm{CO})_{3}\right]^{+\bullet}$, and the following interaction of the latter with the initial clusters, resulting in a cluster $\left[\mathrm{CpReFe}_{2}\left(\mu_{3}-\mathrm{C}=\mathrm{CHPh}\right)(\mathrm{CO})_{6}\right]^{+\bullet}$, which undergoes further reactions. The unpaired electron is seen to be localized on the Fe atom of all the radical cations obtained during the experiments. The characteristic feature of both radical cations $\mathbf{7}^{+\bullet}$ and $\mathbf{8}^{+\bullet}$ obtained from the ReFePd clusters is, thus, the unpaired electron localization on the Fe atom and the rhombic anisotropy of the g-factor. The analogous characteristics were previously reported for the heterometallic trinuclear cluster $\mathrm{Cp}_{2} \mathrm{FeMn}_{2}(\mathrm{CO})_{7}\left(\mu_{3}-\mathrm{S}_{2}\right)_{2}[72]$.

\section{Conclusion}

The electrochemical properties of bi- and trinuclear $\mathrm{Re}, \mathrm{Pd}$ and Fe-containing vinylidene complexes were studied. A combination of electrochemical and spectroscopic methods with chemical redox agents is employed to find out the pathways of redox reactions of the compounds and to determine the products of their electrochemical transformations (the redox transformation schemes see above).

The binuclear complexes $\mathrm{Cp}(\mathrm{CO})_{2} \operatorname{RePd}(\mu-\mathrm{C}=\mathrm{CHPh})\left(\mathrm{PPh}_{3}\right)_{2} \quad(2), \quad \mathrm{Cp}(\mathrm{CO})_{2} \operatorname{RePd}(\mu-$ $\mathrm{C}=\mathrm{CHPh})(\mathrm{P}-\mathrm{P})(\mathrm{P}-\mathrm{P}=\mathrm{dppe}(3)$, dppp (4)) are found to undergo oxidation with the cleavage of the Re-Pd and Pd-C bonds and formation of rhenium complex $\mathbf{1}$ and Pd-containing fragments. Similar results were obtained for the oxidation of $\mathrm{Cp}(\mathrm{CO})_{2} \operatorname{ReFe}(\mu-\mathrm{C}=\mathrm{CHPh})(\mathrm{CO})_{4}(\mathbf{5})$; however, the $\left[\mathrm{Fe}(\mathrm{CO})_{4}\right]^{+}$. fragment formed in the electrochemical reaction is able to further react with the initial unreacted complex $\mathbf{5}$, to give a radical cation of the trinuclear cluster $\left[\mathrm{Cp} \mathbf{R e F e} \mathbf{F}_{2}\left(\mu_{3^{-}}\right.\right.$ $\left.\mathrm{C}=\mathrm{CHPh})(\mathrm{CO})_{8}\right]^{+}$. The one-electron oxidation of clusters $\mathbf{7}$ and $\mathbf{8}$ yields radical cations $\mathbf{7}^{+\bullet}$ and $\mathbf{8}^{+\bullet}$, whose destruction leads to the formation of the corresponding binuclear complexes $\mathbf{3}$ and $\mathbf{4}$ and an iron fragment $\left[\mathrm{Fe}(\mathrm{CO})_{3}\right]^{+}$. The latter reacts with the initial clusters $\mathbf{7}$ and $\mathbf{8}$, to give a trinuclear radical cation $\left[\mathrm{CpReFe} \mathbf{R}_{2}\left(\mu_{3}-\mathrm{C}=\mathrm{CHPh}\right)(\mathrm{CO})_{8}\right]^{+}$, , whose further reaction with binuclear complexes 3 and $\mathbf{4}$ leads to the final products: triangular clusters $(\mathrm{CO})_{\mathbf{8}} \mathbf{F e} \mathbf{e}_{\mathbf{2}} \mathbf{P d}(\mathrm{P}-\mathrm{P})$ and complex 1

In summary, the oxidation processes of the binuclear $\operatorname{ReM}(\mathrm{M}=\mathrm{Pd}, \mathrm{Fe})$ complexes and the trinuclear $\mathrm{ReFePd}$ clusters are established to proceed with the fragmentation of their metallocores and change in the coordination mode of the vinylidene ligand. The coordinatively and electronically unsaturated iron-carbonyl fragments formed in the electrochemical or chemical oxidation reactions of the iron containing complexes ReFe and ReFePd are able to further react with the initial compounds. On the other hand, it is interesting to note that similar pathways of the metal core fragmentation of clusters $\mathbf{7}$ and $\mathbf{8}$ occurred in the case of their 
reactions with $\mathrm{Fe}_{2}(\mathrm{CO})_{9}$, although the formation of complex 1 wasn't observed in both cases due to the presence of $\mathrm{Fe}_{2}(\mathrm{CO})_{9}$.

\section{Acknowledgement}

This work was financially supported by the Presidium of the Russian Academy of Sciences (Multipurpose program for Basic Research, Project No. II.2П/V.44-13).

\section{Experimental}

\section{General considerations}

All the operations and manipulations were carried out under an argon atmosphere. Reagent grate solvents were dried by the standard procedures, stored under argon, and freshly distilled prior to use. All other reagents were obtained from commercial sources and used as received. The compound $\left[\mathrm{Cp}_{2} \mathrm{Fe}\right]\left[\mathrm{BF}_{4}\right]$ was prepared from the commercial ferrocene by published procedure [73]. [ $\left[\mathrm{Et}_{4} \mathrm{~N}\right]\left[\mathrm{BF}_{4}\right]$ (Fluka, puriss. electrochemical grade) was used as purchased. The compounds of $\left[\mathrm{Cp}(\mathrm{CO})_{2} \mathrm{Re}=\mathrm{C}=\mathrm{CHPh}\right] \quad$ (1) [50], $\mathrm{Cp}(\mathrm{CO})_{2} \operatorname{RePd}(\mu-$ $\mathrm{C}=\mathrm{CHPh})\left(\mathrm{PPh}_{3}\right)_{2}$ (2) [37], $\mathrm{Cp}(\mathrm{CO})_{2} \operatorname{RePd}(\mu-\mathrm{C}=\mathrm{CHPh}) \mathrm{L}_{2} \quad\left(\mathrm{~L}_{2}=\operatorname{dppe}(\mathbf{3})\right.$, dppp (4)) and $\mathrm{CpReFePd}\left(\mu_{3}-\mathrm{C}=\mathrm{CHPh}\right)(\mathrm{CO})_{5} \mathrm{~L}_{2}\left(\mathrm{~L}_{2}=\right.$ dppe (7), dppp (8) [64] were prepared according to the described methods. The trinuclear clusters $\mathrm{Cp}(\mathrm{CO})_{2} \mathbf{R e F e}_{2}\left(\mu_{3}-\mathrm{C}=\mathrm{CHPh}\right)(\mathrm{CO})_{6}(\mathbf{6}),(\mathrm{CO})_{\mathbf{8}} \mathbf{F e}_{2} \mathbf{P d L}_{2}$ $\left(\mathrm{L}_{2}=\right.$ dppe (9), dppp (10) and the binuclear complex $\mathrm{Cp}(\mathrm{CO})_{2} \operatorname{ReFe}(\mu-\mathrm{C}=\mathrm{CHPh})(\mathrm{CO})_{4}(\mathbf{5})$ were obtained from the reactions of clusters 7 and 8 with $\mathrm{Fe}_{2}(\mathrm{CO})_{9}$ and isolated by column chromatography as described in [64]. The EPR and IR data were obtained in the Krasnoyarsk Regional Centre of Research Equipment, Siberian Branch of the Russian Academy of Sciences. The electrochemical measurements were performed with an IPC-Pro M potentiostat (Volta, Saint-Petersburg, Russia), interfaced to a computer employing electrochemical software. All the measurements were carried out in a three-electrode home-built cell at room temperature. The EPR experiments were conducted by using a Bruker ELEXSYS E-580 spectrometer. The experiments were made in the temperature range $85-250 \mathrm{~K}$. The experimental EPR spectra were simulated using a Bruker Xsophe program. The IR spectra were recorded on a Vector 22 Infrared Fourier spectrometer (Bruker, Germany). The X-ray data were obtained with an automatic Bruker X8 Apex diffractometer equipped with a two-dimensional CCD detector (Bruker AXS, Germany).

\section{Electrochemical study}

The electrochemical measurements were carried out in acetonitrile solutions with $0.1 \mathrm{M}$ $\left[\mathrm{Et}_{4} \mathrm{~N}\right]\left[\mathrm{BF}_{4}\right]$ as a supporting electrolyte. The cyclic voltammograms and polarograms were recorded on an IPC-Pro M potentiostat (Volta, Saint-Petersburg, Russia) with computer software using a three-electrode system. The working electrode was a stationary platinum electrode of 1 $\mathrm{mm}$ diameter or a stationary glassed carbon (GC) electrode of $3 \mathrm{~mm}$ diameter in a Teflon housings or a dropping mercury electrode (DME) with a positive margin drop $(\mathrm{m}=3.6 \mathrm{mg} / \mathrm{s}, \tau=$ $0.23 \mathrm{~s}$ ). The reference electrode was $\mathrm{Ag} / 0.1 \mathrm{M} \mathrm{AgNO}_{3}$ in $\mathrm{MeCN}$. The auxiliary electrode was a platinum wire. The reference electrode and the auxiliary electrode were separated from the bulk solution in a glass tube filled with an electrolyte solution and fitted with a porous plug. The number of the electrons transferred in a particular redox process was estimated by comparison of the wave height observed with those of the one-electron ferrocene ${ }^{+/ 0}$ or $\mathrm{Cp}(\mathrm{CO})_{2} \mathbf{R e}=\mathrm{C}=\mathrm{CHPh}$ of the same concentration as well as through usual diagnostic electrochemical parameters. The controlled-potential electrolysis was carried out with the IPC-Pro potentiostat using a threeelectrode system with a working platinum electrode of $4 \mathrm{~mm}$ diameter. 


\section{Chemical oxidation of $\left[\mathrm{Cp}(\mathrm{CO})_{2} \operatorname{Re}(\mu-\mathrm{C}=\mathrm{CHPh}) \operatorname{Pd}\left(\mathrm{PPh}_{3}\right)_{2}\right](2)$}

$60 \mathrm{mg}(0.06 \mathrm{mmol})$ of 2 was dissolved in $4 \mathrm{~mL}$ of dichloromethane and treated with 16 $\mathrm{mg}(0.06 \mathrm{mmol})$ of $[\mathrm{Fc}]\left[\mathrm{BF}_{4}\right]$. The color of the solution gradually changed from yellow to orange-red in 5 minutes and new bands of mononuclear complex 1 (1994 and $\left.1920 \mathrm{~cm}^{-1}\right)$ appeared in the IR spectrum instead of the bands of the initial complex $2\left(1928\right.$ and $\left.1854 \mathrm{~cm}^{-1}\right)$. The reaction mixture was evaporated to dryness; the residue was dissolved in petroleum ether and placed on a silica column $(5 \times 2 \mathrm{~cm})$. Two fractions were eluted with the petroleum ether: the yellow one of ferrocene $(10 \mathrm{mg})$ and the rose one of $\left[\mathrm{Cp}(\mathrm{CO})_{2} \mathrm{Re}=\mathrm{C}=\mathrm{CHPh}\right](\mathbf{1})(22 \mathrm{mg}$, $88 \%)$.

The oxidation and treatment of the resulting mixtures of complexes $\mathbf{3}$ and $\mathbf{4}$ was performed in similar ways. The yields of $\mathbf{1}$ are $87 \%$ for $\mathbf{3}$ and $91 \%$ for $\mathbf{4}$.

\section{Chemical oxidation of clusters $\left[\mathrm{CpReFePd}\left(\mu_{3}-\mathrm{C}=\mathrm{CHPh}\right)(\mathrm{CO})_{5}(\mathrm{dppe})\right](7)$}

The solution of $90 \mathrm{mg}(0.09 \mathrm{mmol})$ of cluster $7 \mathrm{in} 5 \mathrm{~mL}$ of dichloromethane was treated with $25 \mathrm{mg}(0.09 \mathrm{mmol})$ of $[\mathrm{Fc}]\left[\mathrm{BF}_{4}\right]$. The color of the solution gradually changed from violetgreen to red-brown. The course of the reaction was monitored by the IR spectroscopy. The reaction continued until the carbonyl bands associated with 7 (2005, 1940, 1914 and $\left.1856 \mathrm{~cm}^{-1}\right)$ disappeared from the IR spectrum and the new ones of mononuclear complex 1 and trinuclear cluster 9 appeared instead. The reaction mixture was filtered through a pad of alumina $(0.3 \times 2$ $\mathrm{cm})$ and evaporated to dryness, the residue was extracted with benzene until the extracts were colorless $(5 \times 2 \mathrm{~mL})$. The combined extracts were evaporated to dryness and redissolved in a benzene-petroleum ether mixture (1:3) and placed on an alumina column $(6 \times 2 \mathrm{~cm})$. Two fractions were eluted with petroleum ether: the yellow one of ferrocene $(15 \mathrm{mg})$ and the rose one of $\left[\mathrm{Cp}(\mathrm{CO}){ }_{2} \mathrm{Re}=\mathrm{C}=\mathrm{CHPh}\right](1)(20 \mathrm{mg}, 54 \%)$. The third violet fraction was eluted with the benzene-petroleum ether (1:1) mixture and after the evaporation of the solvent yielded $17 \mathrm{mg}$ (22 $\%)$ of (dppe) $\mathrm{PdFe}_{2}(\mathrm{CO})_{8}(\mathbf{9})$ as a dark-violet solid.

The oxidation and treatment of the resulting mixtures of cluster $\mathbf{8}$ were performed in a similar way.

\section{Chemical oxidation of $\left[\mathrm{Cp}(\mathrm{CO})_{2} \operatorname{Re}(\mu-\mathrm{C}=\mathrm{CHPh}) \mathrm{Fe}(\mathrm{CO})_{4}\right](5)$}

Complex 5 (56 mg, $0.1 \mathrm{mmol}$ ) was dissolved in $4 \mathrm{~mL}$ of $\mathrm{CH}_{2} \mathrm{Cl}_{2}$ and transferred via cannula into a slurry of $\mathrm{AgBF}_{4} \cdot 3$ (dioxane) $(46 \mathrm{mg}, 0.1 \mathrm{mmol})$ in $\mathrm{CH}_{2} \mathrm{Cl}_{2}$. The change of the reaction mixture color from yellow-orange to orange-red was observed. The IR spectrum of the reaction mixture shown new $v(\mathrm{CO})$ bands of complex 1 and cluster 6 along with the bands from the initial compound. After 20 minutes of stirring the reaction mixture was filtered through a pad of alumina $(0.3 \times 2 \mathrm{~cm})$ from the insoluble silver precipitate and evaporated to dryness. The residue was extracted with benzene until the extracts were colorless $(8 \times 2 \mathrm{~mL})$. The combined extracts were evaporated to dryness and redissolved in a benzene-petroleum ether mixture (1:5) and placed on the alumina column $(8 \times 2 \mathrm{~cm})$. Three fractions were subsequently eluted with a petroleum ether and petroleum ether-benzene (2:1) mixture. The first pale fraction yielded $24 \mathrm{mg}$ of unreacted complex 5. The second and third fractions yielded $11 \mathrm{mg}(44 \%)$ of 1 and $16 \mathrm{mg}$ (39\%) of 6 (based on the recovered initial material).

\section{EPR study}

The radical cations $\mathbf{7}^{+\bullet}$ and $\mathbf{8}^{+\bullet}$ were prepared by the treatment of the initial clusters $\mathbf{7}$ and $8\left(1 \mathrm{mM}\right.$ solution) with $[\mathrm{Fc}]\left[\mathrm{BF}_{4}\right]\left(1 \mathrm{mM}\right.$ or $0.1 \mathrm{mM}$ solution) in $\mathrm{CH}_{2} \mathrm{Cl}_{2}$ or in the $1: 1 \mathrm{CCl}_{4} / \mathrm{CHCl}_{3}$ solvent mixture. The samples were allowed to stand at room temperature for 2.5, 7.5 and 12.5 minutes or at $233 \mathrm{~K}$ for 2 minutes before being transferred into quartz tubes via syringe and frozen in liquid nitrogen. The EPR spectra of the samples were recorded in the temperature range $85-250 \mathrm{~K}$ for the samples in both liquid and solid-state on the Bruker ELEXSYS E-580 spectrometer. The simulated EPR spectra were obtained with the Bruker Xsophe program. 


\subsection{X-ray diffraction studies of $\left[\mathrm{CpReFePd}\left(\mu_{3}-\mathrm{C}=\mathrm{CHPh}\right)(\mathrm{CO})_{5}(\mathrm{dppe})\right](7)$}

Red-green crystals of $\mu_{3}-\left[3 \eta^{2}\right.$-(phenyl)ethane-1,1-diyl-1:2$\left.\kappa^{2} \mathrm{C}\right]$-pentacarbonyl- $1 \kappa^{2} \mathrm{C}, 2 \kappa^{3} \mathrm{C}$ (ethane-1,2-diylbis(diphenylphosphane- $\left.3 \kappa^{2} \mathrm{P}\right)$ )- $\left(1 \eta^{5}\right.$-cyclopentadienyl)-palladiumironrhenium (Re-Fe-Pd) suitable for X-ray diffraction analysis were grown from the acetonitrile solution in a sealed flask under an argon atmosphere at $-20^{\circ} \mathrm{C}$. The acetonitrile was decanted off and the crystals were washed with hexane. $\mathrm{C}_{44} \mathrm{H}_{35} \mathrm{O}_{5} \mathrm{P}_{2} \mathrm{FeRePd} \cdot\left(\mathrm{C}_{2} \mathrm{H}_{3} \mathrm{~N}\right)$, triclinic, $P-1, \mathrm{a}=11.7690(6), \mathrm{b}$ $=15.8882(8), \mathrm{c}=21.4707(12) \AA, \alpha=92.347(2), \beta=99.2166(18)^{\circ}, \gamma=105.0981(17), \mathrm{V}=$ $3811.7(3) \AA^{3}, Z=4$. A single crystal diffraction study was performed at $150 \mathrm{~K}$ on an automatic Bruker X8 Apex diffractometer equipped with a two-dimensional CCD detector. The diffraction data were obtained by the standard procedure. Table 1 lists the crystallographic characteristics and details of the diffraction experiment. Absorption was taken into account semi-empirically using the SADABS program [74]. The structures were solved using the direct method and refined by the full-matrix LSM in the anisotropic approximation using the SHELXTL program package [75]. The position of the hydrogen atoms at the carbon atoms were calculated geometrically and refined in the rigid body approximation (riding model), the other were localized from the electron density difference synthesis and refined in the isotropic approximation. Atomic coordinates nave been deposited in the Cambridge Crystallographic Data Centre (the CCDC code is 1510935), and can be obtained by request at www.ccdc.cam.ac.uk/data_request/cif. 
Table 1. Electrochemistry data of the complexes containing Re, $\mathrm{Pd}$ and $\mathrm{Fe}\left(\mathrm{MeCN}, 0.1 \mathrm{M} \mathrm{Et} \mathrm{NBF}_{4}, 1 \mathrm{MM}, \mathrm{Ag} / 0.1 \mathrm{M} \mathrm{AgNO}\right.$ in $\left.\mathrm{MeCN}\right)$

\begin{tabular}{|c|c|c|c|c|c|c|c|}
\hline \multirow{3}{*}{ № } & \multirow{3}{*}{ Compounds } & \multicolumn{6}{|c|}{$E_{1 / 2}, V(n)$} \\
\hline & & \multicolumn{2}{|c|}{$\mathrm{Pt}$} & \multicolumn{2}{|c|}{ GC } & \multicolumn{2}{|c|}{ DME } \\
\hline & & Ox & Red & Ox & Red & Ox & Red \\
\hline 1 & $\mathrm{Cp}(\mathrm{CO})_{2} \mathbf{R e}=\mathrm{C}=\mathrm{CHPh}$ & $0.33(1)$ & $-2.15(1)$ & $0.36(1)$ & $-2.18(1)$ & - & $\begin{array}{l}-2.21(1) \\
-2.82(1)\end{array}$ \\
\hline 2 & $\mathrm{Cp}(\mathrm{CO})_{2} \operatorname{RePd}(\mu=\mathrm{C}=\mathrm{CHPh})\left(\mathrm{PPh}_{3}\right)_{2}$ & $\begin{array}{c}-0.07(1) \\
0.33(1)\end{array}$ & - & $\begin{array}{l}0.01(1) \\
0.39(1)\end{array}$ & - & - & $\begin{array}{l}-2.40(1) \\
-2.90(2)\end{array}$ \\
\hline 3 & $\mathrm{Cp}(\mathrm{CO})_{2} \operatorname{RePd}(\mu=\mathrm{C}=\mathrm{CHPh})(\mathrm{dppe})$ & $\begin{array}{c}-0.23(1) \\
0.34(1)\end{array}$ & - & $\begin{array}{c}-0.13(1) \\
0.39(1)\end{array}$ & - & $-0.02(1)$ & $\begin{array}{l}-2.82(1) \\
-2.90(2)\end{array}$ \\
\hline 4 & $\mathrm{Cp}(\mathrm{CO})_{2} \operatorname{RePd}(\mu=\mathrm{C}=\mathrm{CHPh})(\mathrm{dppp})$ & $\begin{array}{c}-0.23(1) \\
0.34(1)\end{array}$ & - & $\begin{array}{c}-0.13(1) \\
0.39(1)\end{array}$ & - & $-0.02(1)$ & $\begin{array}{l}-2.82(1) \\
-2.90(2)\end{array}$ \\
\hline 5 & $\mathrm{Cp}(\mathrm{CO})_{2} \operatorname{ReFe}(\mu-\mathrm{C}=\mathrm{CHPh})(\mathrm{CO})_{4}$ & $\begin{array}{c}0.37(2) \\
{[0.33(1) ;} \\
0.41(1)] \\
\end{array}$ & $-1.86^{\mathrm{a}}(1)$ & $\begin{array}{c}0.42(2) \\
{[0.36(1) ;} \\
0.46(1)]\end{array}$ & $\begin{array}{l}-1.77(1) \\
-2.20(1)\end{array}$ & - & $\begin{array}{l}-1.83(1) \\
-2.56(1)\end{array}$ \\
\hline 6 & $\mathrm{Cp}(\mathrm{CO})_{2} \mathbf{R e F e}_{2}\left(\mu_{3}-\mathrm{C}=\mathrm{CHPh}\right)(\mathrm{CO})_{6}$ & $\begin{array}{c}0.41(2) \\
{[0.36(1) ;} \\
0.46(1)]\end{array}$ & $\begin{array}{c}-1.40^{\mathrm{a}}(>1) \\
-1.63(<1) \\
-1.88(1)\end{array}$ & $0.45(2)$ & $\begin{array}{l}-1.32^{\mathrm{a}}(1) \\
-1.58^{\mathrm{a}}(1)\end{array}$ & - & $\begin{array}{c}-1.40(2) \\
{[-1.32(>1) ;} \\
-1.42(<1)] \\
-1.82 \\
-2.36(1)\end{array}$ \\
\hline 7 & $\mathrm{CpReFePd}\left(\mu_{3}-\mathrm{C}=\mathrm{CHPh}\right)(\mathrm{CO})_{5}(\mathrm{dppe})$ & $\begin{array}{c}-0.28^{\mathrm{a}}(1) \\
-0.12(<1) \\
0.08 \\
0.46(1) \\
\end{array}$ & $-1.94^{\mathrm{a}}(1)$ & $\begin{array}{c}-0.28^{\mathrm{a}}(1) \\
-0.13(<1) \\
0.10 \\
0.45(1)\end{array}$ & $-1.92^{\mathrm{a}}(1)$ & $-0.23(1)$ & $\begin{array}{l}-1.97(1) \\
-2.06(1) \\
-2.44(1) \\
-2.80(1)\end{array}$ \\
\hline 8 & $\mathrm{CpReFePd}\left(\mu_{3}-\mathrm{C}=\mathrm{CHPh}\right)(\mathrm{CO})_{5}(\mathrm{dppp})$ & $\begin{array}{c}-0.38^{\mathrm{a}}(<1) \\
-0.23(<1) \\
0.07 \\
0.37(1) \\
\end{array}$ & $-1.85^{\mathrm{a}}(1)$ & $\begin{array}{c}-0.36^{\mathrm{a}}(<1) \\
-0.15(<1) \\
0.41(1)\end{array}$ & $-1.82^{\mathrm{a}}(1)$ & $-0.26(1)$ & $\begin{array}{l}-1.84(1) \\
-1.91(1) \\
-2.85(1) \\
-3.13(1) \\
\end{array}$ \\
\hline 9 & $(\mathrm{CO})_{8} \mathbf{F e}_{2} \mathbf{P d}(\mathrm{dppe})$ & $0.25(1)$ & $-1.48(1)$ & 0.34 & $-1.49^{\mathrm{a}}$ & - & $\begin{array}{l}-1.40^{\mathrm{a}}(2) \\
-2.06(1) \\
-2.30(1)\end{array}$ \\
\hline 10 & $(\mathrm{CO})_{\mathbf{8}} \mathbf{F e}_{2} \mathbf{P d}(\mathrm{dppp})$ & $0.24(1)$ & $\begin{array}{l}-1.43^{\mathrm{a}}(1) \\
-2.30(1)\end{array}$ & 0.30 & -1.42 & $0.24(1)$ & $\begin{array}{l}-1.40(2) \\
-2.25(1) \\
-2.60(1)\end{array}$ \\
\hline
\end{tabular}

${ }^{\mathrm{a}}$ The quasi-reversible study; $\mathrm{n}$ - the number of electrons transferred in a particular electrochemical study (the number of the electrons $\mathrm{n}>1$ or $\mathrm{n}<1$ indicates that the wave height is bigger or smaller than the height of the one-electron wave) 


\section{References}

1. P. Buchwalter, J. Rosé, P. Braunstein, Chem. Rev. 115 (2015) 28.

2. C. Dossi, A. Fusi, E. Grilli, R. Psaro, R. Ugo, R. Zanoni, J. Catal. 123 (1990) 181.

3. L.N. Lewis, Chem. Rev. 93 (1993) 2693.

4. J. Xiao, R.J. Puddephatt, Coord. Rev. 143 (1995) 457.

5. P. Braunstein, J. Rose, Heterometallic Cluster for Heterogeneous Catalysis, in: R.D. Adams, F.A. Cotton (Eds.), Catalysis by Di- and Polynuclear Metal Cluster Complexes. Wiley-VCH., New York, 1998, Ch. 13, p. 443.

6. P.Zanello, F.Fabrizi de Biani, Bimetallic effects on the redox activity of transition-metal carbonyl clusters, in: P. Braunstein, L.A. Oro, P.R. Raithby (Eds.), Metal Clusters in Chemistry, WileyVCH: New York, 1999, p. 1104.

7. J.M. Thomas, B.F.G. Johnson, R. Raja, G. Sankar, P.A. Midgley, Acc. Chem. Res. 36 (2003) 20.

8. L. Wu, M. Shi, Eur. J. Org. Chem. 6 (2011) 1099.

9. J.J. Teesdale, A.J. Pistner, G.P.A. Yap, Y-Z. Ma, D.A. Lutterman, J. Rosenthal, Catalysis Today. 225 (2014) 149.

10. E. Gianotti, V. N. Shetti, M. Manzoli, J. A. L. Blaine, W. C. Pearl, Jr., R. D. Adams, S. Coluccia, and R. Raja, Chem Eur. J. 16 (2010) 8202.

11. R. D. Adams, T. S. Barnard, Organometallics. 17 (1998) 2885.

12. R. D. Adams, J. Organomet. Chem. 600 (2000) 1.

13. R. D. Adams, B. Captan, J. Organomet. Chem. 689 (2004) 4521.

14. R. D. Adams, B. Captan, Angew. Chem. Int. Ed. Engl. 47 (2008) 252.

15. R. D. Adams, B. Captan, L. Zhu, J. Organomet. Chem. 693 (2008) 819.

16. W.E. Geiger, Prog. Inorg. Chem. 33 (1985) 275.

17. N. Toshima, T.Yonezawa, New J. Chem. 22 (1998) 1179.

18. J. Xiao, L. Hao, R.J. Puddephatt, Organometal. 14 (1995) 2194.

19. J. Xiao, L. Hao, R.J. Puddephatt, L. Manojlovic-Muir, K.W.Muir, A.A. Torabi, J. Chem. Soc., Chem. Commun. (1994) 2221.

20. E. Rosenberg, R. Laine, Concepts and models for characterizing homogeneous reactions catalyzed by transition metal cluster complexes, in: R.D. Adams, F.A. Cotton (Eds.), Catalysis by Di- and Polynuclear Metal Cluster Complexes, Wiley-VCH., New York, 1998, Ch. 1, p. $1 .$.

21. V. Ritleng, M.J. Chetcuti, Chem. Rev. 107 (2007) 797.

22. N. Wheatley, P. Kalck, Chem. Rev. 99 (1999) 3379.

23. F. Ungva, Coord. Chem. Rev. 218 (2001) 1.

24. R.D. Adams, J. Organomet. Chem. 600 (2000) 1.

25. R.D. Adams, J. Am. Chem.Soc. 129 (2007) 7545.

26. W. E. Geiger, Organometallics, 26 (2007) 5738.

27. W. E. Geiger, Organometallics, 30 (2011) 28.

28. P. Lemoine, Coord. Chem. Rev. 47 (1982) 56.

29. P. Lemoine, Coord. Chem. Rev. 83 (1988) 169.

30. P. Zanello, Coord. Chem. Rev. 87 (1988) 1.

31. S.R. Drake, Polyhedron, 9 (1990) 455.

32. F.Rossi and P.Zanello, Portugaliae Electrochimica Acta. 29 (2011) 309.

33. A.B. Antonova, Coord. Chem. Rev. 251 (2007) 1521.

34. M.I. Bruce, Chem. Rev. 91 (1991) 197.

35. N.E. Kolobova, L.L. Ivanov, O.S. Zhvanko, G.G. Aleksandrov, Y.T. Struchkov, J. Organomet. Chem. 228 (1982) 265.

36. N.E. Kolobova, L.L. Ivanov, O.S. Zhvanko, A.S. Batsanov, Y.T. Struchkov, J. Organomet. Chem. 279 (1985) 419.

37. A.B. Antonova, O.S. Chudin, N.I. Pavlenko, W.A. Sokolenko, A.I. Rubaylo, A.D. Vasiliev, V. V. Verpekin, O. V. Semeikin, Russ. Chem. Bull. Int. Ed. 58 (2009) 955. 
38. O.S. Chudin, W.A. Sokolenko, V.V. Verpekin, N.I. Pavlenko, A.I. Rubaylo, A.B. Antonova, Zh. Sibirskogo Federalnogo Universiteta. Khimiya. 4 (2011) 424.

39. O.S. Chudin, V. V. Verpekin, G. V Burmakina, A.D. Vasiliev, N.I. Pavlenko, A.I. Rubaylo, J. Organomet. Chem. 757 (2014) 57.

40. A.B. Antonova, O.S. Chudin, A.D. Vasiliev, N.I. Pavlenko, W.A. Sokolenko, A.I. Rubaylo, O. V. Semeikin, J. Organomet. Chem. 694 (2009) 127.

41. H. Werner, F.J.G. Alonso, H. Otto, K. Peters, H.G. Von Schnering, Chem. Ber. 121 (1988) 1565.

42. H. Werner, J. Wolf, G. Müller, C. Kruger, Angew. Chem. Int. Ed. Engl. 23 (1984) 431.

43. H. Werner, A.F.J. Garcia, H. Otto, K. Peters, H.G. Von Schnering, J. Organomet. Chem. 289 (1985) C5.

44. C. Bianchini, A. Meli, M. Peruzzini, F. Zanobini, P. Zanello, Organometallics 9 (1990) 241.

45. C. Bianchini, F. Laschi, F. Ottaviani, M. Peruzzini, P. Zanello, Organometallics 7 (1988) 1660.

46. C. Bianchini, P. Innocenti, A. Meli, M. Peruzzini, F. Zanobini, P. Zanello, Organometallics 9 (1990) 2514.

47. A.J.L. Pombeiro, J. Organomet. Chem. 690 (2005) 6021.

48. D. A. Valyaev, O.V. Semeikin, N.A. Ustynyuk, Coord. Chem. Rev. 248 (2004) 1679.

49. L.N. Novikova, M.G. Peterleitner, K.A. Sevumyan, O.V. Semeikin, D.A. Valyaev, N.A. Ustynyuk, V.N. Khrustalev, L.N. Kuleshova, M.Yu. Antipin, J. Organomet. Chem. 631 (2001) 47.

50. D.A. Valyaev, O.V. Semeikin, M.G. Peterleitner. Y.A. Borisov, V.N. Khrustalev, A.M. Mazhuga, E.V.Kremer, N.A. Ustynyuk. J. Organomet. Chem. 689 (2004) 3837.

51. D.A. Valyaev, M.G. Peterleitner, O.V. Semeikin, K.I. Utegenov, N.A. Ustynyuk, A. SourniaSaquet, N. Lugan, G. Lavigne. J. Organomet. Chem. 692 (2007) 3207.

52. A.A. Johansson, A.B. Antonova, V.A. Truhacheva, G.V. Burmakina, A.I. Rubaylo, N.G. Maksimov., S.V. Kovalenko, N.A. Deykhina, Izv. Akad. Nauk SSSR, Ser.Khim. (1987) 56; Bull. Acad. Sci. USSR, Div. Chem.Sci. 36 (1987) 46 (Engl. Trans.).

53. G.V. Burmakina, S.V. Kovalenko, A.A. Johansson, V.A. Truhacheva, O. V. Baulina, A.B. Antonova, A.G. Ginzburg, Metalloorganich. Khim. 5 (1992) 1244; Organomet. Chem. In the USSR 5 (1992) (Engl. Trans.).

54. A.B. Antonova, A.A. Johansson, N.A. Deykhina, E.D. Korniyets, N.I. Pavlenko, G.V. Burmakina, A.I. Rubaylo, A.G. Ginzburg, P.V. Petrovskii, J. Organometal. Chem. 524 (1996) 81.

55. A.A. Johansson, A.B. Antonova, N.A. Deykhina, D.A. Pogrebnyakov, N.I. Pavlenko, G.V. Burmakina, A.I. Rubaylo, P.V. Petrovskii, A.G. Ginzburg, Zh. Obshch. Khim. 69 (1999) 881; Russ. J. Gen. Chem. 69 (1999) 847 (Engl. Trans.).

56. G.V. Burmakina, N.I. Pavlenko, A.A. Johansson, A.B. Antonova, O.V. Lukicheva, A.I. Rubaylo, T. P. Novikova, D.A. Pogrebnyakov, Zh. Obshch. Khim. 70 (2000) 2029; Russ. J. Gen. Chem. 70 (2000) 1910 (Engl. Trans.).

57. G.V. Burmakina, D.A. Pogrebnyakov, N.I. Pavlenko, A.B. Antonova, A.I. Rubaylo, Zh. Obshch. Khim. 73 (2003) 1413; Russ. J. Gen. Chem. 73 (2003) 1335 (Engl. Trans.).

58. G.V. Burmakina, V.V. Verpekin, O.S. Chudin, D.V. Zimonin, N.I. Pavlenko, A.B. Antonova, A.I. Rubaylo, Zh. Sib. Fed. Univ. Khim. 1 (2013) 51.

59. G.V. Burmakina, N.I. Pavlenko, A.B. Antonova, D.A. Pogrebnyakov, A.I. Rubaylo, Russ. J. Inorg. Chem. 51 (2006) 785 (Engl. Trans.).

60. O.S. Chudin, V. V. Verpekin, G. V Burmakina, A.D. Vasiliev, N.I. Pavlenko, A.I. Rubaylo, J. Organomet. Chem. 757 (2014) 57.

61. G.V. Burmakina, O.S Chudin, V.V. Verpekin, D.V. Zimonin, N.I. Pavlenko, A.B. Antonova, A.I. Rubaylo, Zh. Sib. Fed. Univ. Khim. 4 (2013) 394.

62. Q.L. Suo, H. Zhang, Y. Wang, L. Wang, L. Wen, X. Leng, J. Organomet. Chem. 631 (2001) 87.

63. B. Alonso, C. A . lvarez-Toledano, E. Delgado, E. Hernandez, I. Garcia-Orozco, R. A. Toscano, J. Organomet. Chem. 692 (2007) 5117.

64. V. V. Verpekin, A.A. Kondrasenko, O.S. Chudin, A.D. Vasiliev, G. V. Burmakina, N.I. Pavlenko, A.I. Rubaylo, J. Organomet. Chem. 770 (2014) 42. 
65. A.B. Antonova, D.A. Pogrebnyakov, N.A. Deykhina, Z.A. Starikova, F.M. Dolgushin, A.I. Belokon', Russ. Chem. Bull. 49 (2000) 526.

66. A.J. Bard, L.R. Faulkner, Electrochemical Methods, Fundamentals and Applications, Wiley, New York, 2001.

67. B. Cordero, V. Gomez, A.E. Platero-Prats, M. Reves, J. Echeverria, E. Cremades, F. Barragan, S. Alvarez, Daltone Trans. (2008) 2832.

68. V.V. Verpekin, O.S. Chudin, D.A. Piryazev, A.I. Rubaylo, S.A. Gromilov, O.V. Semeikin, Journal of Structural Chemistry. 56 (2015) 774.

69. A.B. Antonova, A.A. Johansson, N.A. Deykhina, D.A. Pogrebnyakov, N.I. Pavlenko, A.I. Rubaylo, F.M. Dolgushin, P.V. Petrovskii, A.G. Ginzburg, J. Organomet. Chem. 577 (1999) 238.

70. D.Osella, L. Pospisil, J. Fiedler, Organometallics 12 (1993) 3140.]

71. S.D. Molin, C. Cugnet, D. Brevet, D. Lucas, Y. Mugnier, D.Fortin, R.T.Boere, P.D. Harvey, Organometallics 26 (2007) 5209.

72. R. D. Adams, E.M. Boswell, B. Captan, S. Miao, C. Beddie, C.E. Webster, M.B. Hall, N.S. Dalal, N. Kaur, D. Zipse, J. Organomet. Chem. 693 (2008) 2732.

73. N.G. Connelly., W.E. Geiger, Chem. Rev. 96 (1996) 877.

74. Sheldrick G.M. SADABS. Program for Empirical Absorption Correction of Area Detector Data. University of Goettingen, Germany, 1997.

75. M. Sheldrick, Acta Crystallogr. A64 (2008) 112. 